Cornell Law Library

Scholarship@Cornell Law: A Digital Repository

Cornell Law Faculty Publications

Faculty Scholarship

$1-1-1980$

\title{
State Law in Federal Civil Rights Cases: The Proper Scope of Section 1988
}

Theodore Eisenberg

Cornell Law School, ted-eisenberg@lawschool.cornell.edu

Follow this and additional works at: http://scholarship.law.cornell.edu/facpub

Part of the Civil Procedure Commons, and the Civil Rights and Discrimination Commons

\section{Recommended Citation}

Eisenberg, Theodore, "State Law in Federal Civil Rights Cases: The Proper Scope of Section 1988" (1980). Cornell Law Faculty Publications. Paper 697.

http://scholarship.law.cornell.edu/facpub/697

This Article is brought to you for free and open access by the Faculty Scholarship at Scholarship@Cornell Law: A Digital Repository. It has been accepted for inclusion in Cornell Law Faculty Publications by an authorized administrator of Scholarship@Cornell Law: A Digital Repository. For more information, please contact jmp8@cornell.edu. 


\section{STATE LAW IN FEDERAL GIVIL RIGHTS GASES: THE PROPER SCOPE OF SEGTION 1988}

\section{TheOdore EISENBerg†}

The Constitution is not what it used to be. In the 1960s vindication of individual rights through expansions in constitutional doctrine became commonplace. Although the Burger Court slowed that trend, it has continued and in some respects expanded another trend in federal law - the protection of individual rights by means of federal civil rights statutes. Today, the cutting edge of substantive civil rights doctrine consists of comprehensive modern civil rights legislation and of revitalized civil rights statutes of the Reconstruction era. Given the prominence of federal legislation in the civil rights field, a statute that threatens to defederalize the national civil rights program is of great significance. This Article concerns such a provision, 42 U.S.C. $§ 1988 .^{1}$

Section 1988 is now known primarily for the civil rights attorney's fees provision appended to it in $1976,{ }^{2}$ but the corpus to which the 1976 amendment was fastened is of substantial interest and potential influence in its own right. Superficially, section 1988 appears to be a choice-of-law provision instructing federal courts hearing civil rights cases to fill the inevitable gaps in federal statutes with compatible state law. That seemingly straightforward reading, however, has embroiled the courts in continuing controversies. Section 1988's interpreters have been unable to agree on criteria for deciding when federal law is in need of supplementation, or when state rules, once examined, nevertheless may be ignored as undermining federal civil rights policy. The Supreme Court and the lower federal courts have espoused inconsistent interpretations:

† Acting Professor of Law, University of California, Los Angeles. B.A. 1969, Swarthmore College; J.D. 1972, University of Pennsylvania. I would like to thank my colleagues, Kenneth L. Karst, Gerald P. Lopez, and Stephen C. Yeazell, for their helpful comments, and Sharon Rudnick for her able research assistance. Generous financial support was provided through research grants from the Dean's Fund of UCLA Law School and the Academic Senate of UCLA.

142 U.S.C. $\$ 1988$ (1976).

2 Civil Rights Attorney's Fees Awards Act of 1976, Pub. L. No. 94-559, §2, 90 Stat. 2641 (codified as the second sentence of 42 U.S.C. \$1988 (1976)). 
one approach threatens to place important aspects of federal civil rights litigation at the mercy of state law, while others appear to render section 1988 meaningless.

These difficulties reflect a widespread misunderstanding of section 1988. Despite its appearance, that section was not meant to be a general instruction to fill gaps in federally created causes of action with state rules, and it makes little sense when it is so used. In this Article, I sketch the existing anomalies in section 1988 doctrine before attempting to show that current approaches to section 1988 suffer from one of two problems. They either are logically flawed or require federal courts in civil rights cases to apply state rules of decision that are both unrelated to federal civil rights policy and inconsistent with nationwide uniformity in the adjudication of civil rights actions. I then argue that section 1988, when viewed as part of the larger provision from which it derives-section 3 of the Civil Rights Act of $1866^{3}$-makes sense today only when it is applied to actions that are removed from state to federal court pursuant to civil rights removal provisions. ${ }^{4}$ In such cases section 1988 is an instruction, perhaps unneeded, to apply the state's substantive law when that law is the basis for the action removed to federal court. ${ }^{5}$ But when the cause of action is federal, as it is, for example, in cases brought under section $1983,{ }^{6}$ the central statutory vehicle for vindicating constitutional rights, section 1988's instruction to apply state law is inapplicable.

Relegating section 1988 to a deserved obscurity does have a cost. At present, courts may at least mumble something about section 1988 before filling gaps in federally created civil rights actions. What guidance do they have once section 1988 is out of the picture? One need only recall the interstitial nature of federal law, which regularly obliges federal courts to flesh out federal statutory programs. Whatever principles courts follow in choosing law to round out these other federal statutes should provide adequate guidance for filling the interstices of federally created civil rights actions. The important point is that section 1988 is not a command by Congress to fill those gaps by reference to state law. Although federal courts may choose to follow state law, they do have a choice. Courts erroneously have believed that in section 1988 Congress expressly or impliedly meant to restrict or influence that selection.

3 Ch. 31, 14 Stat. 27.

428 U.S.C. $\$ 1443$ (1976).

5 For example, in a murder trial removed from state to federal court, $\S 1988$ orders the federal court to apply the state substantive law of murder.

642 U.S.C. $\$ 1983$ (1976). 


\section{Inconsistencies, Paradoxes, ANd Section 1988}

Little of what follows will be comprehensible without some effort by the reader to parse section 1988, which provides in pertinent part:

The jurisdiction in civil and criminal matters conferred on the district courts by the provisions of this Title, and of Title "GIVIL RIGHTS," and of Title "CRIMES," for the protection of all persons in the United States in their civil rights and for their vindication, shall be exercised and enforced in conformity with the laws of the United States, so far as such laws are suitable to carry the same into effect; but in all cases where they are not adapted to the object, or are deficient in the provisions necessary to furnish suitable remedies and punish offenses against law, the common law, as modified and changed by the constitution and statutes of the State wherein the court having jurisdiction of such civil or criminal cause is held, so far as the same is not inconsistent with the Constitution and laws of the United States, shall be extended to and govern the said courts in the trial and disposition of the cause, and, if it is of a criminal nature, in the infliction of punishment on the party found guilty.?

The courts' failure to interpret section 1988 consistently is understandable for it is difficult to divine its meaning merely by reading it. This difficulty is not solely a problem of communication between section 1988's nineteenth-century drafters and contemporary lawyers. Almost one hundred years ago Justice Clifford termed the provision "a mere jumble of Federal law, common law, and State law, consisting of incongruous and irreconcilable regulations, which ... amounts to no more than a direction to a judge [to conduct proceedings] as well as he can." 8

One might guess that much of the perplexity surrounding section 1988's interpretation could be dispelled by thoughtful and detailed analysis. Indeed, at least four neglected questions emerge in parsing section 1988, none of which has been satisfactorily answered and some of which have been completely ignored. When is federal law "deficient" or "not adapted to the object" within the meaning of section 1988? What follows when federal law is found to be deficient? What is section 1988's role in criminal prosecutions? Why is section 1988 limited to civil rights cases? Surely, one might

7 Id. $\$ 1988$.

8 Tennessee v. Davis, 100 U.S. 257, 299 (1880) (Clifford, J., dissenting). 
think, serious study of these questions would substantially further progress towards a solution of the problems of interpreting section 1988.

Yet attempting to understand section 1988 solely by examining its entrails is fundamentally misguided. Although, following a brief introduction to the case law, I shall address those four questions in more detail than any court has done, I do not claim that focusing on them will explain away the inconsistency of section 1988 law or lead to some irrefutable interpretation. Detailed analysis of the language of section 1988 will lead not to "good" answers, but to even greater complexity and frustration, a result that suggests the courts have been working in the wrong frame of reference. To make sense of section 1988 an entirely new approach must be ventured, one that interprets the current wording of the statute in its original context. ${ }^{9}$

\section{A. Section 1988 in the Courts}

Robertson $v$. Wegmann, ${ }^{10}$ the Supreme Court's most recent encounter with section 1988, is a useful starting point for study because it raises typical section 1988 issues and resolves at least some of them in a questionable manner. Robertson did not originate as a battle between obscure figures that wound its way to the Supreme Court to enshrine unknown litigants in the annals of American jurisprudence. It started as a dispute between Jim Garrison and Clay Shaw, two prominent figures in the turmoil following President Kennedy's assassination. In 1969, Garrison, then district attorney for the Louisiana parish containing New Orleans, prosecuted Shaw on charges of conspiracy to assassinate the President.11 Soon after his acquittal, Shaw was arrested on charges of having committed perjury at his conspiracy trial. In a section 1983 action in federal district court, Shaw obtained an injunction against the pending state prosecution and sought damages against Garrison and

9 For those who have, based on their own experience, already despaired of understanding $\$ 1988$ merely by reading it, some of part I, comprising text accompanying notes 7-91, will reinforce prior frustrations. Such readers may wish to skip to part II, comprising text accompanying notes 92-139 infra, in which I offer a new reading of the statute. Those who have not dealt with $\S 1988$, however, may benefit from a serious effort to make sense of the provision without breaking from the universally held view that $\$ 1988$ guides federal courts on choice-of-law matters in cases arising under federal law. If nothing else, the unsatisfactory results of such an exercise should serve to make one more amenable to part II's fresh look at $\S 1988$.

10436 U.S. 584 (1978).

11 Robertson v. Wegmann, 436 U.S. 584, 586 (1978). 
others, including Robertson, an alleged financial backer of Garrison's investigations. ${ }^{12}$ Shaw died before the scheduled trial on his damage action. When Shaw's executor, Wegmann, was substituted as plaintiff, Garrison and the other defendants moved to dismiss on the ground that the action abated upon Shaw's death. ${ }^{13}$ The case thus squarely posed the issue whether a section 1983 action survives the death of the plaintiff.

Had the Court ignored section 1988, it might have followed the traditional common law rule that tort actions do so abate, ${ }^{14}$ or it might have construed the language and purpose of section 1983 to evidence a congressional desire to have such actions survive..$^{15}$ The Court believed, however, that it was bound to follow other guidance, and it therefore did not choose either of these relatively straightforward lines of analysis. Instead it rested its decision upon an interpretation of section 1988.

An inquiry into section 1988's origins might have shed some light on the statute's perplexing syntax, for section 1988 has a revealing past. The Court chose, however, to interpret section 1988 primarily by reading it. By its terms, the section applies in civil rights cases adjudicated in federal court. In such cases, section 1988 becomes relevant only when federal laws are "not adapted to the object, or are deficient in the provisions necessary to furnish suitable remedies." 18 In Robertson, there was little doubt that the case involved civil rights, and the district court, the court of appeals, and the Supreme Court all concluded that federal law was deficient or not adapted to the object. ${ }^{17}$ The Supreme Court reiterated prior observations that federal law does not cover every issue likely to arise in a civil rights action and that survival of actions was one such neglected area. ${ }^{18}$ In cases of federal law deficiency, section

12 Shaw's effort to enjoin a state criminal proceeding succeeded in the district court before the Supreme Court's decision in Younger v. Harris, 401 U.S. 37 (1971), narrowed the circumstances under which such injunctions should issue. Even before Younger, however, there were few cases in which state prosecutors were enjoined on the ground of bad-faith harassment. See Fiss, Dombrowski, 86 YArE L.J. 1103, 1115-16 n.36 (1977). The court of appeals, which heard Shaw's case after Younger had been decided, found that Younger's requirements for injunctive relief had been satisfied. Shaw v. Garrison, 467 F.2d 113, 122 (5th Cir.), cert. denied, 409 U.S. 1024 (1972).

13 Robertson v. Wegmann, 436 U.S. 584, 586-87 (1978).

14 See, e.g., W. Prosser, Handbook of the Law of Torts $\$ 126$ (4th ed. 1971).

15 See 436 U.S. at 595 (Blackmun, J., dissenting).

1642 U.S.C. $\$ 1988$ (1976).

17436 U.S. at 586, $589-90 \&$ n.4.

18 Id. 589 (citing Moor v. County of Alameda, 411 U.S. 693, 702 n.14 (1973)). 
1988 instructs a court to employ "the common law, as modified and changed by the constitution and statutes of the State" 19 in which the federal court sits. Under Louisiana's survivorship statutes, which provided that actions like Shaw's survive only in favor of certain relatives, all parties agreed that Shaw's claim would abate. ${ }^{20}$ The dispute centered on whether adherence to the Louisiana statutory scheme was permissible in light of the caveat at the end of section 1988, that state laws be applied only when they are "not inconsistent with the Constitution and laws of the United States." 2 I

Both the district court and the court of appeals concluded that abatement under Louisiana law was inconsistent with the policies of section $1983,{ }^{22}$ and noted that adoption of a federal rule in favor of survival would generate uniformity in applying section 1983. The Supreme Court reached a different result. The Court indicated that the policies underlying section 1983 include compensation for victims of official misconduct and prevention of abuse of state power, but it believed that neither of these policies would be seriously damaged by application of Louisiana's survivorship laws. ${ }^{23}$ The Court observed that, on the whole, Louisiana's law was not hostile to survival of actions, and in no way was it specifically hostile to survival of federal civil rights actions. ${ }^{24}$ Shaw just happened not to be survived by the right class of relatives. The Court rejected the notion that a state rule causing a plaintiff to lose a federal civil rights action could, without more, be deemed inconsistent with federal law. ${ }^{25}$ Having found Louisiana's laws not inconsistent with section 1983, the Court held that Louisiana's rule of survivorship governed and that Shaw's executor's action should be dismissed.26

Although in Robertson the Court read section 1988 as a command to apply state law in the face of federal statutory silence, the Court has not always adhered to that reading. In Sullivan v. Little Hunting Park, Inc., ${ }^{27}$ the Court relied on section 1988 in implying the existence of a damage remedy under 42 U.S.C. $\S 1982$, a provi-

1942 U.S.C. \$1988 (1976).

20 Robertson v. Wegmann, 436 U.S. 584, 587-88 (1978).

2142 U.S.C. $\$ 1988$ (1976).

22436 U.S. at 587-88.

23 Id. 592.

24 Id. 591-92.

25 Id. 593.

26 Id. 594-95. For a recent application of the Robertson analysis to survival of an action based on 42 U.S.C. $\$ 1981$ (1976), see Gee v. CBS, Inc., 471 F. Supp. 600, 614-17 (E.D. Pa. 1979).

27396 U.S. 229 (1969). 
sion barring private racial discrimination in the sale and rental of property. ${ }^{28}$ The Sullivan Court viewed section 1988 as giving the federal courts freedom to choose between state and federal rules rather than binding them to follow state law: "Compensatory damages for deprivation of a federal right are governed by federal standards, as provided [in] ... $\$ 1988 . .$. This means, as we read $\S 1988$, that both federal and state rules on damages may be utilized, whichever better serves the policies expressed in the federal statutes." 29

Whether or not the Court's interpretation is a fair statement of the content of section 1988, that interpretation is not consistent with the Court's approach in Robertson.$^{30}$ According to Robertson, when federal law is silent section 1988 binds federal courts to apply the common law as modified by state rules unless those rules conflict with federal mandates. In Sullivan, Robertson's approach would have led the Court to inquire whether the common law as modified by state law allowed a private damage action. Furthermore, under Robertson, the mere fact that application of a state rule would defeat the action would not necessarily render the state rule inconsistent with federal law. Although the Court in Sullivan might have gone on to find the state rule inconsistent with federal law for other reasons, the primary inquiry would have focused on state standards. Conversely, if the Court had followed the Sullivan approach in Robertson, the inquiry would not have been whether section 1988 mandates adherence to the state survivorship rule, but whether the state rule or a federal rule would better serve the policies expressed in federal civil rights statutes. ${ }^{31}$

28 In Jones v. Alfred H. Mayer Co., 392 U.S. 409 (1968), the Court had read $\$ 1982$ to bar racial discrimination by private persons in such real estate transactions, but had left open the question whether an aggrieved party could sue for damages. Id. 414 n.I4. Section 1982 itself makes no mention of remedies. Damage actions may also be brought under 42 U.S.C. $\S 1981$ (1976). See Johnson v. Railway Express Agency, 421 U.S. 454, 459-60 (1975).

29 Sullivan v. Little Hunting Park, Inc., 396 U.S. 229, 239-40 (1969); accord, Carter v. Carlson, 447 F.2d 358, 369 (D.C. Cir. 1971), rev'd on other grounds sub nom. District of Columbia v. Carter, 409 U.S. 418 (1973). In a characterization of $\$ 1988$ that predates Sullivan, Professor Amsterdam termed the section a "broad authorization" for federal courts to employ effective remedies in civil rights cases. Amsterdam, Criminal Prosecutions Affecting Federally Guaranteed Civil Rights: Federal Removal and Habeas Corpus Jurisdiction to Abort State Court Trial, 113 U. PA. L. REv. 793, 829 n.152 (1965).

30 See Robertson v. Wegmann, 436 U.S. 584, 596 (1978) (Blackmun, J., dissenting).

31 It is also revealing to compare the approach to $\$ 1988$ in Robertson with that articulated a few months earlier in Carey v. Piphus, 435 U.S. 247 (1978). In a footnote in Carey, the Court characterized $\S 1988$ as authorizing "courts to look to the common law of the States where this is "necessary to furnish suitable 
The lower courts have not achieved greater success in formulating a uniform approach to section 1988. In Basista $v . W e i r,{ }^{32}$ the Court of Appeals for the Third Circuit faced two questionswhether punitive damages could ever be awarded in a section 1983 action, and whether, if they could, recovery of at least nominal damages was a prerequisite. The court concluded that federal law was not deficient on these points and that it allowed punitive damages even in the absence of other damages. ${ }^{33}$ Yet a district court interpreting section 1988 intimated that the availability of punitive damages in civil rights actions would turn on whether state law allowed punitive damages in similar cases. ${ }^{34} \mathrm{~A}$ second area of inconsistency concerns the issue of a superior officer's liability for the acts of a subordinate. The Court of Appeals for the Ninth Circuit, applying section 1988, held in Hesselgesser $v$. Reilly ${ }^{35}$ that the answer turns on the superior's liability under state law. Yet many circuit courts, without alluding to section 1988, have found no vicarious liability for supervisors in section 1983 cases. $^{3 \mathrm{C}}$

remedies' under $\$ 1983 . ”$ Id. 258 n.13 (quoting 42 U.S.C. $\$ 1988$ (1976)). The tenor of the footnote seems closer to the view of $\S 1988$ expressed in Sullivan than to that adopted in Robertson.

32340 F.2d 74 (3d Cir. 1965).

33 Id. 87.

34 Claiborne v. Illinois Cent. R.R., 401 F. Supp. 1022, 1026 (E.D. La. 1975) (dictum), modified, 583 F.2d 143 (5th Cir. 1978), cert. denied, 99 S. Ct. 2869 (1979). Although the case presented no $\$ 1983$ issues, the district court found $\S 1981$ to be an independent source authorizing an award of punitive damages. 401 F. Supp. at 1027. For more direct holdings that state damage rules may shape recoveries in $\$ 1983$ actions, see Duchesne v. Sugarman, 566 F.2d 817, 821 n.2 (2d Cir. 1977); James v. Murphy, 392 F. Supp. 641, 645 (M.D. Ala. 1975); Jones v. Hildebrant, 191 Colo. 1, 7-9, 550 P.2d 339, 344-45 (1976) (en banc), cert. dismissed as improvidently granted, 432 U.S. 183 (1977).

In Carey v. Piphus, 435 U.S. 247 (1978), without implying approval or disapproval, the Supreme Court cited a series of cases supporting punitive damage awards under $\$ 1983$. Id. 257 n.11.

35440 F.2d 901, 903 (9th Cir. 1971). Accord, Duncan v. Edwards, 600 F.2d 1069, 1070 (5th Cir. 1979) (not expressly relying on $\$ 1988$ ); Baskin v. Parker, 588 F.2d 965, 968 (5th Cir.) (not expressly relying on \$1988), opinion withdrawn on rehearing, 602 F.2d 1205 (5th Cir. 1979); Hansen v. May, 502 F.2d 728, 730 (9th Cir. 1974) (citing Hesselgesser); Boettger v. Moore, 483 F.2d 86, 87 (9th Cir. 1973) (citing Hesselgesser); Scott v. Vandiver, 476 F.2d 238, 242 (4th Cir. 1973); McDaniel v. Carroll, 457 F.2d 968, 969 (6th Cir. 1972), cert. denied, 409 U.S. 1106 (1973); Lewis v. Brautigam, 227 F.2d 124, 128 (5th Cir. 1955) (not expressly relying on $\$ 1988$ ). In Moor v. County of Alameda, 411 U.S. 693, 704 n.17 (1973), the Supreme Court discussed Hesselgesser and Lewis without questioning their holdings. As the Fifth Circuit's recent withdrawal of its opinion in Baskin emphasizes, however, the supervisory liability of state officials may have to be reconsidered in light of Monell v. Department of Social Servs., 436 U.S. 658, 691-95 (1978), and Rizzo v. Goode, 423 U.S. 362, 370-71 (1976).

36 See Reimer v. Short, 578 F.2d 621, 625 (5th Cir. 1978), cert. denied, 440 U.S. 947 (1979); Duchesne v. Sugarman, 566 F.2d 817, 830 (2d Cir. 1977); Sebastian v. United States, 531 F.2d 900, 904 (8th Cir.), cert. denied, 429 U.S. 856 (1976); Williams v. Vincent, 508 F.2d 541, 546 (2d Cir. 1974); Schmidt v. 
These cases demonstrate not only that conflicts exist in the courts' approaches to section 1988, but that the proper interpretation of the statute cannot turn on a desire to expand or contract the scope of liability for civil rights violations. Depending upon the state rule to be applied in the federal action, section 1988 may increase the number of cases in which liability is found, as in Hesselgesser, or decrease it, as in Robertson. The need for a more stable approach to section 1988 is thus independent of differingviews on the proper reach of federal civil rights remedies.

\section{B. Sources of Inconsistency: Interpretive Problems Raised by Section 1988}

It seems rather late in section 1988's checkered life to offer in print a detailed reading of the statute, but no one has yet done so. Courts dealing with section 1988 seem preoccupied with the result it produces and do not pause to give opinion readers the benefit of the intermediate analytical steps that must precede a conclusion that state law is or is not applicable. Commentators have all but ignored section $1988 .{ }^{37}$ In this subpart, I attempt to penetrate the thicket that surrounds the section by focusing first on two issues that must be resolved before section 1988 can be read as commanding deference to state law and then on two larger questions about its structure. The unsatisfactory results of this analysis suggest that a major shift is needed in our thinking about section 1988.

One threshold issue, largely neglected by the courts that rely on section 1988 to apply state law in civil rights cases, is the determination that federal law is "deficient" or "not adapted to the object." Unless such a finding is made, section 1988 does not

Wingo, 499 F.2d 70, 73-74 (6th Cir. 1974); Floyd v. Trice, 490 F.2d 1154, 1157 (8th Cir. 1974) (dictum); Dunham v. Crosby, 435 F.2d 1177, 1179-80 (Ist Cir. 1970), overruled in part, Raper v. Lucey, 488 F.2d 748, 751 n.3 (1st Cir. 1973). At least one case mentioned $\$ 1988$ before reaching a result contrary to Hesselgesser v. Reilly, 440 F.2d 901 (9th Cir. 1971). See Knipp v. Weikle, 405 F. Supp. 782, 783-84 (N.D. Ohio 1975).

Knipp and cases like it confirm that something has gone awry in judicial interpretations of $\$ 1988$. For although courts have divided over the impact of $\S 1988$ on the issue of vicarious liability under $\$ 1983$, they have largely ignored the possible influence of $\S 1988$ and state law on many other defense and immunity issues. See text accompanying notes $41-48$ infra.

37 Exceptions are Theis, Shaw v. Garrison: Some Observations on 42 U.S.C. If 1988 and Federal Common Law, 36 LA. L. Rev. 681 (1976); Comment, Choice of Law Under Section 1983, 37 U. Chr. L. Rev. 494 (1970). See also S. NArmod, Civin Righrs \& Civi Libertmes Litigation $\$ \$ 3.16,3.17,4.01$, at 96-97, 4.03, at $105,4.08$ (1979); Amsterdam, supra note 29 , at 829 n.152. At least one commentator has observed tension in the Supreme Court's recent decisions construing $\$ 1988$. See Schnapper, Civil Rights Litigation After Monell, 79 Colum. L. Rev. 213,265 (1979). 
command resort to state law. The courts' implicit tests for determining deficiency-there are no explicit tests-lead to troublesome results. A second thorny problem arises once federal law is deemed deficient, thereby triggering section 1988's instruction to apply state law. State law seems inappropriate as a mandatory guide for settling many issues that arise in civil rights cases, even those that are purely remedial. But can one neglect state law without rendering section 1988 meaningless? The dilemma of a federal statute containing instructions seemingly at odds with federal policy lies at the heart of judicial confusion about section 1988.

In addition to these problems of interpretation that surface in the typical section 1988 case, another pair of questions concerns two puzzling aspects of the statute that have eluded judicial attention. Although section 1988 traditionally has been used to resolve questions arising in civil actions, on its face the statute purports to operate as well in the criminal sphere. In criminal cases, in which the remedy-the criminal penalty-is prescribed by statute, the remedial issues that Sullivan and other cases have found suitable for resolution under section 1988 are absent. What conceivable role can section 1988 play in criminal prosecutions? Finally, the statutory language invites inquiry into section 1988's limitation to civil rights cases. If Congress thought it appropriate to fill the gaps in federal civil rights legislation with state law, why did it choose not to extend section 1988's choice-of-law rule to remedy similar gaps in non-civil rights statutes? ${ }^{38}$

\section{The Deficiency Finding}

Because each court relying on section 1988 to invoke state law must first decide that federal law is in some sense deficient, the standards governing the deficiency determination are central to articulating the scope of section 1988. I shall explore four possible tests of deficiency. First, one could hold that federal law is deficient only if no federal statute speaks to a question. Second, one could find a deficiency more frequently than under the first test by deeming federal law deficient when the statute conferring the

38 Section 1988 has also played a prominent role in determining the applicable limitations period for federal civil rights actions. See, e.g., Beard v. Robinson, 563 F.2d 331, 334-35 (7th Cir. 1977), cert. denied, 438 U.S. 907 (1978); Buckner v. Goodyear Tire \& Rubber Co., 339 F. Supp. 1108, 1117 (N.D. Ala. 1972), aff'd, 476 F.2d 1287 (5th Cir. 1973). This determination normally would be made by reference to state law without any guidance from $\$ 1988$. See, e.g., Johnson v. Railway Express Agency, 421 U.S. 454, 462 (1975); Johnson v. Davis, 582 F.2d 1316, 1318 (4th Cir. 1978); Baker v. F \& F Inv., 420 F.2d 1191, 1196 n.7 (7th Cir.), cert. denied, 400 U.S. 821 (1970). 
cause of action, section 1983 in most civil rights cases, does not expressly address an issue. Third, one could go beyond the face of the statute creating the cause of action and delve into its legislative history in an effort to discover the intent of Congress on the issue in question. Fourth, one could break with the notion that "law" is limited to legislation, and view federal law as wanting only when both federal statutory and decisional law are silent on a matter.

The first test is not very appealing. Even if issues that arise in civil rights cases happen to be mentioned in other federal statutes, there is no reason to think that those non-civil rights statutes would provide a rule of law tailored to the policies underlying civil rights legislation. For the same reason, when those unrelated non-civil rights statutes are silent, nothing would be gained by the forced application of a state law that is equally unconcerned with the federal civil rights program. Finally, the Supreme Court's decision in Robertson would appear to reject a deficiency test based on provisions in other federal statutes. In that case, the Court expressly chose to ignore a survivorship provision in a civil rights statute and looked instead to state law..$^{39}$ The test for deficiency should not and does not turn on whether any federal statute mentions the issue in question.

The second possible test for the deficiency of federal law-that federal law is not "adapted to the object" when the federal statute creating the cause of action fails to address the issue-may be implicit in Robertson. Because section 1983, the basis of the suit, is silent about survival of actions, the Robertson Court held that section 1988 required deference to state law. If this reading of Robertson is correct, then there are many issues with respect to which section 1983 is deficient and which are, therefore, susceptible to governance by state law via section 1988. The issue of punitive damages, de-

39436 U.S. at 589 n.4. 42 U.S.C. $\$ 1986$ (1976) (emphasis added) provides:

Every person who, having knowledge that any of the wrongs conspired to be done, and mentioned in section 1985 of this title, are about to be committed, and having power to prevent or aid in preventing the commission of the same, neglects or refuses so to do, if such wrongful act be committed, shall be liable to the party injured, or his legal representatives, for all damages caused by such wrongful act, which such person by reasonable diligence could have prevented; and such damages may be recovered in an action on the case; and any number of persons guilty of such wrongful neglect or refusal may be joined as defendants in the action; and if the death of any party be caused by any such wrongful act and neglect, the legal representatives of the deceased shall have such action therefor, and may recover not exceeding $\$ 5,000$ damages therein, for the benefit of the widow of the deceased, if there be one, and if there be no widow, then for the benefit of the next of kin of the deceased.

For the origins of this provision, see Monell v. Department of Social Servs., 436 U.S. $658,665-69$ (1978). 
cided in Basista $v$. Weir, ${ }^{40}$ provides one example. Although section 1983 mentions actions at law or equity and presumably contemplates some form of damage remedy, it says nothing about the availability of punitive damages and can scarcely be said to determine whether an award of compensatory or nominal damages is a prerequiste to a punitive award. Likewise, section 1983 does not address a host of other issues, including the burden of proof, immunities, supervisory liability, affirmative defenses, and statutes of limitations. Must federal law therefore be deemed deficient on all these matters? ${ }^{41}$

Such a defederalization of section 1983 would not sit well, and in fact has been impliedly rejected by the Supreme Court's disposition of a number of cases deciding important issues under section 1983 without any hint of a need to resort to state law. Defenses to section 1983 actions, although colored by a background of general tort law, do not turn on the law of the forum state. ${ }^{42}$ Thus, in Wood v. Strickland ${ }^{43}$ and in Scheuer $v$. Rhodes, ${ }^{44}$ the Court set forth defenses to section 1983 actions without mention of section 1988 or state law. And the Court has seen fit to handle the liability of superior officers and government entities for misbehavior by subordinate officials in Rizzo $v$. Goode, ${ }^{45}$ in Monroe v. Pape, ${ }^{46}$

40340 F.2d 74 (3d Cir. 1965).

41 For example, in assessing judicial immunity from suit, a question that $\S 1983$ does not address, why do courts not look to state immunity rules? Reliance on $\$ 1988$ to invoke state law might have led to a result opposite to that reached by the Court in Stump v. Sparkman, 435 U.S. 349 (1978), a recent judicial immunity case. See Rosenberg, Stump v. Sparkman: The Doctrine of Judicial Impunity, 64 VA. L. REv. 833, 842 n.43 (1978). Nor does $\$ 1983$ describe a police officer's defenses to damage actions, an issue that state law addresses. Courts may be in disagreement over the degree to which state law should shape those defenses. See Note, "Vicarious Immunity" of Private Persons in Section 1983 Actions: "An Unexamined Assumption," 28 CASE W. REs. L. Rev. 1014, 1023 n.66 (1978).

One court has invoked $\S 1988$ to justify resort to state law to resolve what it termed an issue of standing in a $\$ 1983$ case. Landrum v. Moats, 576 F.2d 1320, 1323 n.2 (8th Cir. 1978). In Landrum, the question was whether the mother of the deceased victim of a police shooting could maintain a $\$ 1983$ action. The court characterized the issue as one of standing, which seems something of a misnomer. See Robertson v. Wegmann, 436 U.S. 584 (1978).

42 See generally S. NAmMOD, supra note 37 , at $\$ \$ 8.01-8.15$. Of course, state law may indirectly influence defenses to $\$ 1983$ actions because a reasonable, goodfaith reliance on state law will insulate an executive official from damage liability. But the scope of the defense, and the decision to allow state law to influence that scope, are matters within the discretion of the federal judiciary. Use of state law in these circumstances, unlike use of state law pursuant to $\$ 1988$, is not mandated by Congress.

43420 U.S. 308 (1975).

44416 U.S. 232 (1974).

45423 U.S. 362 (1976).

46365 U.S. 167 (1961), overruled in part, Monell v. Department of Social Servs., 436 U.S. 658 (1978). 
and in Monell v. Department of Social Services ${ }^{47}$ without inquiry into state rules of liability. ${ }^{48}$

In civil rights actions other than those brought under section 1983, reliance on statutory silence to support a deficiency in federal law would also lead, under section 1988's choice-of-law rule, to deciding major federal questions according to state law. For example, neither section $1981^{49}$ nor section 1982,50 which confer upon blacks equal rights to make and enforce contracts and to purchase and hold real property, expressly creates a private cause of action. Both statutes lack the express reference to suits at law or actions in equity contained in section 1983. Whether an action should be implied from the bare existence of a statutory standard is a difficult question, one which has been answered in different ways for different statutes. ${ }^{51}$ Yet if failure of federal statutes expressly to address an issue is the touchstone of deficiency under 1988, courts should decide the availability of causes of action for violations of sections 1981 and 1982 by reference to state law. In Sullivan, the Court was able to avoid such a result with respect to section 1982 only by torturing the language of section 1988 into supporting the principle that the farthest-reaching remedy, state or federal, should govern.

Allowing a finding of deficiency under section 1988 to turn solely on federal statutory silence is unsatisfactory because it gives section 1988, and its commitment to state law, too broad a scope.

47436 U.S. 658 (1978).

48 One could try to distinguish these issues from those decided in Sullivan and Robertson on the ground that the Sullivan-Robertson issues were more clearly "remedial" and that $\$ 1988$ 's primary focus is to guide courts in choosing remedies. Such an effort fails for two reasons. First, $\S 1988$ 's language is not susceptible to a reading that limits the section's operation to questions of remedy. It also instructs courts to resort to state law when federal laws are not "adapted to the object." Second, if one is troubled by having substantive federal civil rights issues turn on state law, there will surely come a point at which one is troubled by having remedial issues resolved by state standards. Can it seriously be proposed that the availability of punitive damages in federal civil rights cases, a remedial question if ever there was one, should turn on state law? Indeed, it has been argued that federal courts should rely on state law less frequently when the issues are remedial. See Note, The Federal Common Law, 82 HaRv. L. Rev. 1512, 1523-25 (1969).

4942 U.S.C. $\S 1981$ (1976).

$50 I d$. 1982.

51 Private cause of action implied: e.g., Transamerica Mortgage Advisors, Inc. v. Lewis, 48 U.S.L.W. 4001 (Nov. 13, 1979); Cannon v. University of Chicago, 99 S. Ct. 1946 (1979); Blue Chip Stamps v. Manor Drug Stores, 421 U.S. 723 (1975).

No private cause of action implied: e.g., Touche Ross \& Co. v. Redington, 99 S. Ct. 2479 (1979); Piper v. Chris-Craft Indus., 430 U.S. 1 (1977); Cort v. Ash, 422 U.S. 66 (1975). 
A third test for deficiency might move beyond the face of the federal statute creating the action and examine its legislative history. In some cases, such a test might be successful in determining that Congress meant to speak to an issue by implication. But Congress does not and cannot be expected to cover in its deliberations all the issues it wants resolved by a federal statute. Nor can it anticipate all the problems that may arise after a statute's enactment. Thus, repairing to the legislative history is not likely to decrease significantly the instances of federal law deficiency or to narrow the scope that section 1988 gives to state law. Nor are courts likely to be much more comfortable in concluding that federal law fails to cover an issue on the basis of silent legislative history than on the basis of silence in the statute.

Moreover, setting up a test for deficiency based on legislative silence leads to easily manipulable results. On the one hand, congressional silence may be interpreted as a failure to establish a federal rule and as demonstrating an intent to leave the issue to state law. ${ }^{52}$ On the other hand, it is almost always possible to argue by negative implication that Congress did consider and resolve a question. Section 1983, for example, makes no express mention of official immunity, nor does the legislative history speak to that question. One might conclude that Congress did address the important issue of immunity by its silence and chose not to allow civil rights violators that defense. ${ }^{53}$ Obviously, if silence is evidence of addressing an issue, federal law will rarely, if ever, be deficient. A satisfactory approach to the deficiency determination is thus unlikely to emerge from interpretations of legislative silence, and courts have not employed it.

52 See, e.g., Ammlung v. City of Chester, 355 F. Supp. 1300 (E.D. Pa. 1973), affd, 494 F.2d 811 (3d Cir. 1974). The court in Ammlung held that the state statute of limitations controlled an action brought under $\$ 1983$ and construed congressional silence as an indication that Congress "has been and is satisfied in having state limitation statutes govern federal civil rights claims." Id. 1308. Although the Ammlung court viewed $\$ 1988$ as a choice-of-law provision, see id. 1304, it probably would have reached the same result under the interpretation of the statute advanced in this Article because it followed a rule that applies independently of $\S 1988$ to federal causes of action in general. See note 38 supra and part III, comprising text accompanying notes $140-45$ infra.

On the issue whether the state tolling provisions also controlled, the court was uncertain whether Congress's tacit incorporation of state limitation periods should also be construed to endorse state tolling rules, and went on to rely on judicial precedent rather than legislative history in concluding that the state provisions did control. See 355 F. Supp. at 1308-11.

53 But see Pierson v. Ray, 386 U.S. 547, 554-55 (1967), in which the Court inferred from the lack of a "clear indication" in the legislative record that $\$ 1983$ was not meant to abrogate the common law immunity of judges. The Court made no mention of $\$ 1988$ or of the deficiency issue. 
There is a fourth possible point of reference for judging whether federal law is deficient. The forbear of section 1988 was enacted prior to the overruling of Swift $v$. Tyson..$^{54}$ Although, Swift, even in its heyday, seemed only to bless a federal common law of commerce, ${ }^{55}$ it is conceivable that those who enacted the ancestor of section 1988 believed there to be a federal common law governing many classes of cases in federal courts. If the term "laws of the United States," as originally used in section 1988's predecessor, meant to include such a general federal common law, then one could test federal law for deficiency not just by examining federal statutes, but also by exploring whatever portions of federal common law seemed pertinent. Today, the existing body of federal decisional law could be supplemented with the growing number of areas in which courts create federal common law..$^{56}$

It is doubtful, however, that a test for deficiency encompassing federal common law represents any advance beyond the statutory tests. Allowing section 1988's choice between federal and state law to hinge upon prior federal court decisions seems no less haphazard than allowing it to turn on the wording or legislative history of federal statutes. And like the first statutory test that contemplated resort to non-civil rights statutes to fill the gaps in federal law, there is no reason to expect that a rule drawn from areas of unrelated federal common law would provide satisfactory guidance to a court deciding a civil rights case. ${ }^{57}$

As with interpretations of section 1988 by negative implication, a deficiency test based on federal common law may render section 1988's reference to state law meaningless. Consider, for example, an action brought under section 1983 in which the issue, as in Basista, is the availability of punitive damages. Given the silence of section 1983, the focus then turns to the federal common law. If the common law is pressed with sufficient determination and enough tenuous analogies are drawn, doubtless an answer will be extracted (1938).

5441 U.S. (16 Pet.) I (1842), overruled, Erie R.R. v. Tompkins, 304 U.S. 64

55 See, e.g., M. Horwitz, The Transformation of American Law 17801860 , at 245 (1977).

${ }^{56}$ See generally Friendly, In Praise of Erie-And of the New Federal Common Law, 39 N.Y.U. L. REv. 383 passim (1964). Judge Friendly argues that Erie R.R. v. Tompkins, 304 U.S. 64 (1938), led to the emergence of a "specialized common law" in areas of truly national concern.

57 In addition, the task of applying "the" federal common law would be complicated by disagreements as to the nature and substance of such law. See R. BrmWeit \& R. Whitten, The Constrtution AND the CoMmon LAw Xi-Xy (1977). 
to this and to any other question concerning section $1983 .{ }^{58}$ If one is willing to press so hard, however, federal law will never be deficient, state law will never apply, and section 1988's choice-oflaw provision will deteriorate into nonsense. ${ }^{59}$

A deficiency test that allows resort to the federal common law, if it is to make any sense, must yield answers for some, but not all, issues that arise in civil rights cases. In those cases in which resort to federal common law does not supply a federal rule of decision, the same problem occurs that has plagued every test for federal law deficiency thus far considered: rather than fashion a federal rule attuned to the specific congressional policies underlying the civil rights program, courts aware of section 1988 may believe themselves

58 Indeed, courts have been inventive in searching non-civil rights laws to come up with rules for $\S 1983$ cases.

With the growth of federal powers and responsibilities the body of federal law has increased dramatically. There is a large and diverse accumulation of federal precedents. Pritchard v. Smith [289 F.2d 153 (8th Cir. 1961)], a section 1983 case, suggests a few of the sources from which a federal rule might be drawn: the admiralty jurisdiction, the Federal Employers Liability Act, and the Sherman Act. At least one section 1983 case relied solely on an antitrust case as controlling precedent [Lauderdale v. Smith, 186 F. Supp. 958 (D. Ark. 1960)]. Other possible sources of federal law include diversity cases which, prior to Erie v. Tompkins [304 U.S. 64 (1938)], were decided according to a federal common law, cases decided in the courts of the District of Columbia, and cases drawn from the areas where federal courts have felt that protection of federal interests requires the development of a federal common law.

Comment, supra note 37, at 497-99 (footnotes omitted). In Basista itself the court relied in part on a pre-Erie diversity decision, Press Publishing Co. v. Monroe, 73 F. 196 (C.C.S.D.N.Y.), appeal dismissed, 164 U.S. 105 (1896), to justify a federal rule of damages in $\$ 1983$ cases. 340 F.2d at 87 .

59 For example, one may question whether the announcement in Basista of a federal rule of damages really turned on the aged precedents the court relied upon. If the court would have applied a federal rule regardless of the availability of precedent, it becomes difficult, if not impossible, responsibly to determine when federal law is deficient.

A frenzied search for federal precedent may have another cost.

A further problem with an extensive search for federal precedent . . . is that the process of finding a federal case to cite for a particular rule or outcome may obscure the more important consideration: are the issues raised by the case of the nature that require a federal rule or would the application of state rules be more satisfactory? A clear statement of the reasons for using a federal rule can guide future decisions; a citation to an admiralty, or antitrust, or employers liability case sheds little on the development of rules for the protection of civil rights.

Comment, supra note 37 , at 499 . It is likely, however, that when a state rule seems suitable, the search for a federal precedent is less thoroughly conducted. See, e.g., Brazier v. Cherry, 293 F.2d 401, 405 (5th Cir.), cert. denied, 368 U.S. 921 (1961). In Brazier, the court felt it unnecessary to examine plaintiff's historically documented contention that 42 U.S.C. $\$ 1986$ (1976) itself granted a personal right of action to the "legal representatives" of the injured person. The court felt it was clear "that Congress adopted as federal law the currently effective state law on the right of survival. This was done by $\S 1988 . " 293$ F.2d at 405. 
bound to apply state law. ${ }^{60}$ Any correspondence between the result and civil rights policy will be entirely fortuitous. Whatever value the common law has in filling gaps in statutory schemes, the schemes themselves, together with relevant background, would often seem at least an equally appealing source of law.

Finally, a test for deficiency based on the federal common law is difficult to square with the text of section 1988. That text provides initially that in civil rights cases the "laws of the United States" shall govern. A few words later, section 1988 instructs that "the common law" shall be used when United States laws are deficient. This juxtaposition makes it doubtful that the term "laws" was meant to include federal common law. Unless Congress had two kinds of common law in mind, one federal and the other state, and set out to disguise its meaning with obscure draftsmanship, it is hard to conceive that the reference to "laws of the United States" means anything other than federal statutory law.

Thus, the most mechanical and unappealing tests for deficiency under section 1988, those that turn solely on study of federal statutes, are the only tests reconcilable with section 1988's language. The fundamental problem with each is inflexibility. Once a deficiency is found, courts are thrust towards state law without regard to the propriety of the state rule and without regard to whether a federal rule would be more appropriate. ${ }^{61}$ So long as section 1988's concept of deficiency is viewed as referring to gaps in federal law, this problem is unavoidable. Exposition of a new solution to the enigma of "deficiency" must await completion of the analysis of section 1988.

\section{Beyond Deficiency: Two Common Laws and the Inconsistency Clause}

Assume, notwithstanding the above analysis, that the difficulties in deciding when federal law is deficient within the meaning of section 1988 can be overcome. Once the deficiency finding is made, two additional problems present themselves. For after federal law - "the laws of the United States" in the language of the statute-is found to be deficient, section 1988 instructs courts to turn to the "common law" as modified by state law. As used in this context, "common law" is ambiguous and could refer either to state decisional law or to the general federal common law that existed when

60 See Robertson v. Wegmann, 436 U.S. 584 (1978).

61 Nor can $\$ 1988$ 's inconsistency clause save this situation. See text accompanying notes 73-79 infra. 
the precursor to section 1983 was passed.62 Both possible choices. are unattractive, however, because they fail sufficiently to contract the role of state rules in federal civil rights actions. A second problem involves section 1988's proviso that state law governs only insofar as it is not inconsistent with federal law, a clause that some view as allowing rejection of state rules when they lead to troublesome results. Despite the Supreme Court's allusion to this possibility in Robertson, ${ }^{63}$ that view proves to be unacceptable.

\section{a. Choice of Common Law}

If federal law is deficient on a matter, section 1988 instructs that "the common law, as modified and changed by the constitution and statutes of the State wherein the court having jurisdiction ... is held, so far as the same is not inconsistent with the Constitution and laws of the United States, shall be extended to and govern the said courts." ${ }^{64}$ There are different possible paths to follow in implementing this instruction, for there is not a single common law to incorporate into federal law. At a minimum the Supreme Court has told us that one must choose between the common law of the state in which the federal court sits and the "kind of general common law that was an established part of our federal jurisprudence by the time of $\S 1988$ 's passage in 1866." 65

Neither choice is particularly appealing. If the states' common law is chosen, the situation feared by a number of courts results in

62 Of course, $\S 1988$ 's reference to the "common law" can include federal common law only if the "Taws of the United States" can be deficient despite federal common law that is on point. For if one must look to federal common law in deciding the deficiency issue, then a finding of deficiency means that federal common law is "not adapted to the object," and it becomes pointless to re-examine that deficient law in following $\$ 1988$ 's directive to resort to the "common law."

One legislator suggested another interpretation of $\$ 1988$ 's directive to apply common law, an interpretation that does not appear to have any support in the statute's language. Congressman Kerr argued that $\$ 3$ of the Civil Rights Act of 1866, the precursor to $\$ 1988$, authorized judicial legislation:

[T] he authors of this bill feared ... that the system of laws heretofore administered in the Federal courts might fail to supply any precedent to guide the courts in the enforcement of the strange provisions of this bill, and not to be thwarted by this difficulty, they confer upon the courts the power of judicial legislation, the power to make such other laws as they may think necessary. . . . That is to say, the Federal courts may, in such cases, make such rules and apply such law as they please, and call it common law.

Cong. Globe, 39th Cong., Ist Sess. 1271 (1866) (emphasis in original). Notwithstanding Congressman Kerr's interpretation, $\$ 3$ appears to refer to an existing body of law.

63 See text accompanying notes 76-77 infra.

6442 U.S.C. $\$ 1988$ (1976).

65 Robertson v. Wegmann, 436 U.S. 584, 589-90 n.5 (1978). 
which important aspects of cases involving sections 1981, 1982, and 1983 then turn upon the happenstance of state law. ${ }^{68}$ For example, if the issue were the availability or scope of official immunity, one would have to scour state law for analogous situations on which to base a rule for federal civil rights actions. ${ }^{67}$ Yet it seems inconceivable that Congress intended one rule of immunity to govern civil rights actions in Pennsylvania and another to govern in New Jersey. Strict uniformity may not be absolutely necessary to an effective civil rights program, but surely a Congress that feared the inadequacies of state law ${ }^{68}$ intended the federal program to be free of the nonuniformity that mandatory resort to such law produces. So strong is the sentiment that a federal rule should govern in civil rights cases that courts have done elaborate doctrinal dances to evade the apparent thrust of section 1988. The insupportable conclusion in Sullivan that the statute offers a choice between state and federal law is one example of this phenomenon. ${ }^{69}$ The Basista court had another ploy. It delved deeply into the federal common law and, lo and behold, discovered a rule of punitive damages. ${ }^{70}$

Interpreting section 1988 as referring to a general, as opposed to state, common law also raises difficulties. If, as the Supreme Court suggested in Robertson, section 1988 refers to the general common law that existed when section 1988's precursor was enacted, federal courts will forever be referring back to rules of a different legal era to govern modern problems for which those rules will only fortuitously supply suitable answers. Furthermore, because section 1988 mandates use of "the common law, as modified and changed by the constitution and statutes of the State," 71 the term, "common law," however interpreted, in most cases will pro-

66 See, e.g., Basista v. Weir, 340 F.2d 74, 86-87 (3d Cir. 1965).

67 It is highly unlikely that there would be direct guidance on this issue.

68 See Monroe v. Pape, 365 U.S. 167, 173-78 (1961), overruled in part on other grounds, Monell v. Department of Social Servs., 436 U.S. 658 (1978).

69 See text accompanying notes 27-31 supra.

70 The Basista court's use of Press Publishing Co. v. Monroe, 73 F. 196 (C.C. S.D.N.Y.), appeal dismissed, 164 U.S. 105 (1896), as precedent is criticized in Comment, supra note 37, at 498 n:23. Two other cases relied upon in Basista, Nixon v. Herndon, 273 U.S. 536 (1927), and Wayne v. Venable, 260 F. 64 (8th Cir. 1919), are voting rights cases. Reliance on such federal precedents to support allowance of punitive damages, $340 \mathrm{~F} .2 \mathrm{~d}$ at 88 , merely shifts the inquiry from whether Basista was correctly decided to whether the precedents were. At some point, courts must decide the punitive damages question without the benefit of direct precedent. Then, under reigning views of $\$ 1988$, the question whether the silence of federal law mandates use of state law is unavoidable.

7142 U.S.C. $\$ 1988$ (1976) (emphasis supplied). 
vide no escape from the happenstance of state law. ${ }^{72}$ In those few instances in which state law is silent and an unmodified federal common law rule can be applied, any congruence between the rule and the policies of the civil rights acts will, once again, be fortuitous.

Thus, whether section 1988's command to apply "the common law" is interpreted as referring to state or federal common law, state rules of decision will nonetheless play an excessive role in federal civil rights actions. In the effort to avoid that result, courts desirous of giving effect to the federal civil rights program will be forced to take embarrassing doctrinal positions.

\section{b. Section 1988's Inconsistency Clause}

To avoid applying state law in federal civil rights cases, courts. might rely on a portion of section 1988 not yet discussed. Section 1988's choice-of-law rule appears not to be ironclad: it provides that courts shall decline to apply state law when state law is inconsistent with federal law. There are at least three possible approaches to this inconsistency clause, none of which satisfactorily resolves the problems of construing section 1988.

First, one might deem state law inconsistent with federal law whenever application of state law would destroy uniformity or otherwise frustrate policies embodied in a federal cause of action. ${ }^{73}$ Section 1988 would then make little sense, however, for resort to state law will always preclude a uniform federal rule. Nullification of section 1988 might perhaps be avoided by adopting a second, not-so-extreme view, requiring less than strict, nationwide uniformity in civil rights actions. Recognizing the value of flexibility in adjudicating civil rights suits, one could deem state law consistent with federal law, even though rules vary among states, so long as state law does not restrict federal civil rights actions. According to this view, as in Sullivan, section 1988 becomes a provision under which state law may expand but not contract federal causes of action. But this approach again raises a question as to whether section 1988 has any meaning. As the Court in Robertson noted in responding

72 See Robertson v. Wegmann, 436 U.S. 584, 589-90 n.5 (1978), in which the Court noted that it need not decide whether the reference to common law refers to general federal or state common law, because in either case, a state statute clearly governed.

73 See generally Basista v. Weir, 340 F.2d 74 (3d Cir. 1965). Although the Basista court did not rest its decision on $\$ 1988$ 's inconsistency clause, the court's reluctance to allow a nonuniform rule to govern the availability of damages in $\$ 1983$ cases, see id. 86 n.11, and its resulting "discovery" of a federal rule of damages, see notes 59 \& 70 supra, are tantamount to deeming all state laws inconsistent with federal law and inventing a new federal rule. 
to the argument that restrictive state rules were automatically inconsistent with federal law:

A state statute cannot be considered "inconsistent" with federal law merely because the statute causes the plaintiff to lose the litigation. If the success of the $\$ 1983$ action were the only benchmark, there would be no reason at all to look to state law, for the appropriate rule would then always be the one favoring the plaintiff, and its source would be essentially irrelevant. But $\S 1988$ quite clearly instructs us to refer to state statutes; it does not say that state law is to be accepted or rejected based solely on which side is advantaged thereby. ${ }^{74}$

The Robertson Court articulated a third position on the inconsistency issue. Sensitive to the need to give section 1988 some meaning, the Court also attempted to leave room, even in survivorship cases, to avoid applying state law. According to Robertson, although state laws are not rendered inconsistent with federal law merely because applying state law would cause the plaintiff to lose, a finding of inconsistency might follow if state law were generally inhospitable or significantly restrictive of the federal cause of action. ${ }^{75}$ Thus, the Court left open the possibility that some state survivorship schemes would fail section 1988's inconsistency test and would not operate to abate a section 1983 action. ${ }^{76}$ The Court may have been particularly worried about actions abating when the constitutional violation that gave rise to the section 1983 action was itself the cause of the plaintiff's death. A rule allowing abatement of such actions would provide violators of constitutional rights with an incentive to kill the victims of their acts. ${ }^{77}$

Robertson's reservation-that overly restrictive state laws might be inconsistent with the spirit, if not the letter, of federal lawpresents new difficulties. It is no simple matter to point to the federal law with which the state law is inconsistent. Only two candidates exist. For example, in Robertson, an unduly restrictive state-law survivorship scheme might be said to be inconsistent either with the federal statute giving rise to the action, in this case section 1983, or another federal law. Upon examination, neither choice ultimately proves attractive.

74436 U.S. at 593.

75 Id. 594.

$76 I d$.

77 For a few of the opinions in which courts have recoiled from such a result, see Brazier v. Cherry, 293 F.2d 401 (5th Cir.), cert. denied, 368 U.S. 921 (1961); Jones v. McElroy, 429 F. Supp. 848, 852 (E.D. Pa. 1977). 
Using section 1983 as a measure of the consistency of a state survivorship scheme with federal law is analytically unsatisfactory. The consistency issue is reached in section 1988 analysis only if federal law initially has been found deficient. It seems to defy logic to hold both that section 1983 says nothing about the survival of actions and that state survivorship laws can be inconsistent with section 1983. The problem is not unique to section 1983 actions; it will recur whenever an attempt is made to find state law inconsistent with a "deficient" federal statute giving rise to the action. State law cannot be said, in any meaningful sense, to be inconsistent with a federal law expressly found not to deal with the issue covered by the state law. To interpret section 1988's inconsistency clause as the Court suggested in Robertson would thus deprive the notion of inconsistency of its ordinary meaning.

Although a state survivorship scheme being analyzed under section 1988 could not be inconsistent with section 1983, the federal statute creating the cause of action, a scheme that violates other federal laws could be ignored under the inconsistency clause. For example, state rules that deny survival only to actions of black decedents could not pass muster under the inconsistency clause because they would violate the fourteenth amendment ${ }^{78}$ and section 1981.79 A test that finds inconsistency when state laws violate federal laws other than the one creating the cause of action gives section 1988's use of the term "inconsistent" a meaning that is in accord with ordinary usage. Significantly, however, this approach to the inconsistency clause gives it a more limited role than that suggested in Robertson. Because no federal statute speaks to survivorship generally, or to survival of section 1983 actions in particular, it is difficult to see how the Court would be able to treat a "significantly restrictive" state survivorship scheme as a violation of federal law. Absent an unlikely holding that survival of actions is constitutionally required, application of Louisiana's rules to a case in which the unconstitutional act itself was the cause of the plaintiff's death would not violate federal law. Thus, although a valid test for inconsistency can be articulated that looks to federal laws other than the one giving rise to the action, that construction cannot be extended to provide the escape hatch for which the Court was searching in Robertson. It is simply not possible, consistently with the language of section 1988, for the Court to decide whether to apply state law by looking to the desirability of the result.

78 U.S. Const. amend. XIV, $\$ 1$.

7942 U.S.C. $\$ 1981$ (1976). 
Once the inconsistency clause's limited scope is recognized, section 1988 presents a dilemma. On the one hand, if a deficiency in federal law is found whenever federal law is silent then, notwithstanding section 1988's inconsistency clause, many critical questions of federal civil rights law will turn on state law. This will lead both to nonuniformity when it seems inconceivable that Congress meant non-national rules to apply and to the possible frustration of federal civil rights policy. On the other hand, if federal statutory silence is not construed as establishing the deficiency of federal law, no satisfactory method of determining deficiency exists, and section 1988's command to apply state law will never be operative. The Court has impaled itself on each horn of this dilemma. In Sullivan, the Court felt it was clearly unacceptable to have state law determine the existence of a federal cause of action, so it misread section 1988 to allow a choice of the more liberal remedial scheme. ${ }^{80}$ In Robertson, in which the issue-survival of the action-seemed less vital and state law not hostile, the Court was more concerned that nothing would be left of section 1988 if it were not applicable in that case. 81 The Court thus ignored the implications of finding a deficiency in federal law on the basis of statutory silence, perhaps deluding itself into believing the inconsistency clause to be more of a safety valve than it really is. ${ }^{82}$

\section{Section 1988's Applicability to Criminal Cases}

Prospects for making sense of section 1988's deficiency and inconsistency clauses, although not great, are relatively bright when compared to the prospects for understanding the provision's application to criminal cases. In federal criminal prosecutions, virtually none of the issues to which section 1988 has been applied in civil actions arises. One need not to invoke section 1988 to determine whether a cause of action exists, the issue in Sullivan, whether an action survives the plaintiff's death, the issue in Robertson, or whether punitive damages are available, the issue in Basista. Furthermore, questions concerning remedies in criminal proceedings

80396 U.S. at 240.

81436 U.S. at 593.

82 One further mystery appears on the face of $\$ 1988$. Suppose that federal law is found to be deficient on an issue and that state law is found to be inconsistent with the laws of the United States within the meaning of $\S 1988$. Given the silence of federal law and unacceptability of state law, what law is a federal court to apply? Under these circumstances, $\$ 1988$, which apparently goes into great detail to provide federal courts with choice-of-law rules, is silent. For an explanation of $\$ 1988$ 's silence under these circumstances, see note 98 infra \& text accompanying notes $97-98$ infra. 
are not as complex as they tend to be in civil proceedings. Typically, the criminal statute imposes a range of sentences, and the judge picks a sentence within the range. Yet section 1988's reference to the criminal provisions of the United States Code and its explicit instruction to apply state law "in the infliction of punishment on the party found guilty" in criminal cases, ${ }^{83}$ leave no doubt that the statute was intended to operate in criminal cases.

One possibility is that section 1988 was an unsophisticated version of the Assimilative Crimes Act. ${ }^{84}$ That Act criminalizes behavior in a federal enclave that would be criminal in the state in which the enclave is located. If section 1988 were to serve a similar function in criminal cases then it would instruct federal courts, whether or not the offending behavior occurred on a federal enclave, to incorporate state criminal provisions into substantive federal criminal law whenever behavior that interfered with civil rights was criminal under state law but not under federal law.

This attempt to breathe life into the criminal aspect of section 1988 seems flawed on at least two grounds. First, using section 1988 to create new federal crimes is inconsistent with the statute's structure. The criminal provisions referred to in section 1988 are those contained in Title 18. The reference contemplates an independent body of substantive federal criminal law-the crimes specified in Title 18-that would give rise to cases in which section 1988 might apply. Section 1988's language does not seem to leave room for the statute to be an independent source of substantive federal criminal law. Indeed in civil actions, the Supreme Court has rejected the argument that section 1988 creates an independent cause of action, ${ }^{85}$ and it can no more appropriately be viewed as doing so in criminal cases. Second, the uniformity issue, so troublesome on the civil side of section 1988, again emerges on the criminal side. It is hardly likely that Congress meant to criminalize behavior in one state but not another..$^{86}$

8342 U.S.C. $\$ 1988$ (1976).

8418 U.S.C. $\$ 13(1976)$.

85 Moor v. County of Alameda, 411 U.S. 693, 703-07 \& n.17 (1973).

86 The Assimilative Crimes Act does allow for variation among states in behavior that violates federal law. But it does so for reasons not applicable in cases to which $\$ 1988$ might apply. The exclusive power of Congress to regulate certain federal enclaves, see U.S. Const. art. 1, $\S 8$, cl. 17; art. 4, $\$ 3$, cl. 2, creates a legal gap that the Assimilative Crimes Act partly fills. Unless federal statutes make state criminal laws applicable to behavior on federal enclaves, reprehensible behavior, even if criminally punishable in every state, becomes noncriminal merely because the behavior occurs on a federal enclave. This anomaly created the pressure that led to enactment of the Assimilative Crimes Act. See 39 AnNals of CoNG. 929 (1823) (remarks of Rep. Buchanan). In filling the gap, the Assimilative 
These considerations raise a second possibility-that section 1988 is not a source of substantive federal criminal law, but merely an authorization for federal courts to supplement federal procedure in criminal cases. One problem with this view is an historical one. Although federal criminal procedure was not codified when section 1988's precursor was enacted, that procedure was not underdeveloped. It was an amalgamation of common law rules, but it did not have huge gaps. Federal criminal jurisdiction thrived without section 1988, and there was no general need to borrow from state law. ${ }^{87}$ Indeed, one of the strengths of early federal criminal procedure was that it was not bound to follow archaic state rules, ${ }^{88}$ a flexibility that this view of section 1988 would not provide. Furthermore, when Congress wished to borrow state criminal procedural rules, it did so by specifically incorporating the desired procedure. ${ }^{89}$ Given Congress's ability to make its wishes clear, it is not likely that Congress intended section 1988's vague language to authorize

Crimes Act achieves uniformity between the law applied to a federal enclave and the law applied to the rest of the state in which the enclave is located. Understandably, this is deemed more important than uniformity in the law applied to federal enclaves in different states. Indeed, one could achieve uniformity among enclaves in different states only by enactment of a general federal substantive criminal law of a scope comparable to that of the criminal law of a state. In civil rights cases, however, there is no corresponding need to incorporate state law into federal criminal law. Federal civil rights statutes neither create gaps in the law nor raise the spectre of a general federal code of criminal law. Rather, the federal civil rights criminal program is shaped by the overriding federal interest in punishing violations of certain federal rights. The goal of intrastate uniformity between state and federal law is therefore subordinate to that of providing protection to federal interests on a nationwide basis.

87 See Scaffidi v. United States, 37 F.2d 203, 207 (1st Cir. 1930). See also United States v. Nye, 4 F. 888, 890 (C.C.S.D. Ohio 1880); United States v. Shepard, 27 F. Cas. 1056, 1058 (E.D. Mich. 1870) (No. 16,273), for the view that state laws do not control federal criminal proceedings.

88 Orfield, Early Federal Criminal Procedure, 7 WaYne L. Rev. 503, 504 (1961) (citing National CoMm'N on Law OBSERVANCe and EnForcement, Report on Cruminat Procedure 32 (1931)).

89 For example, for many years federal juror qualification standards were governed by state rules. See, e.g., Rev. Stat. $\$ 800,18$ Stat. 150 (1875). In addition, at about the time $\S 1988$ 's forbear, $\S 3$ of the Civil Rights Act of 1866, was passed, Congress instructed that state rules were to govern the competency of witnesses to testify in federal court. Id. $\$ 858,18$ Stat. 162 (1875). For other examples of federal incorporation of state criminal procedure, see Judiciary Act of $1789, \mathrm{ch} .20$, $\S 33,1$ Stat. 91; id. ch. 20, $\$ 29,1$ Stat. 88; Act of May 13, 1800, ch. 61, 2 Stat. 82; Act of July 20,1840, ch. 67, 5 Stat. 394 (series of provisions adopting state law on matters pertaining to federal jurors). For many instances in which federal criminal procedure did not follow state rules, see Orfield, supra note 88.

Despite the specific federal provisions mandating use of state law in criminal cases, at least one court viewed $\$ 1988$ as a general instruction to follow state criminal procedures and purported to rely on state law in judging a challenge to action by a grand jury. United States v. Olmstead, 7 F.2d 756, 758 (W.D. Wash. 1925). In Olmstead, however, federal cases were relied on in addition to state procedural rules. Id. 759. It seems that the same result would have been reached without relying on state law. 
a wholesale incorporation of state criminal procedure. Thus, whether interpreted as directing federal courts to apply state substantive or procedural criminal law, section 1988's application to criminal cases is problematic.

\section{Section 1988's Limitation to Civil Rights Cases}

A fourth major problem in understanding section 1988 concerns its express limitation to civil rights cases. On the average, federal civil rights statutes are no more nor less complete than federal statutes regulating other areas. What was it about the exercise of civil and criminal jurisdiction in civil rights cases that prompted Congress to enact section 1988?

One possible explanation of the differential treatment apparently accorded civil rights cases is discernible in Sullivan. There the Court read section 1988 as a command in civil rights cases to use whichever remedy, state or federal, is the more far-reaching. Sullivan could be viewed as manifesting the often-articulated view that civil rights provisions, more than others, should be "liberally construed" to further their purposes. ${ }^{90}$ Although this approach to section 1988 would serve to separate civil rights actions from other actions arising under federal law, it bears little, if any, relation to the language of the statute. Section 1988 requires an initial conclusion that federal law is deficient whereupon state law governs. That section nowhere gives a court freedom to choose the more liberal remedial structure. Not surprisingly, the Court effectively discarded the Sullivan approach in the more recent case of Robertson and applied a restrictive state statute requiring dismissal of the action. The "liberal construction" view also encounters special difficulties in criminal cases. For the maxim that civil rights laws should be liberally construed clashes here with the maxim that criminal provisions must be construed strictly, a true dilemma for maxim followers. ${ }^{91}$ This dilemma suggests that if Congress intended section 1988 as an instruction to follow the rules most protective of civil rights, it would not also have included criminal cases within the statute's compass. The attempt to explain section

90396 U.S. at 237. For an original formulation of this view, see the statement by Rep. Shellabarger, introducing the precursor of $\S 1983$, $\S 1$ of the Ku Klux Klan Act of 1871: "This Act is remedial and in aid of the preservation of human liberty and human rights. All statutes and constitutional provisions authorizing such statutes are liberally and beneficently construed ... [and] the largest latitude consistent with the words employed is uniformly given in construing such statutes." Conc. GLOBE, 42d Cong., Ist Sess., App. 68 (1871), quoted in Lake Country Estates, Inc. v. Tahoe Regional Planning Agency, 440 U.S. 391, 400 n.17 (1979).

91 E.g., United States v. Naftalin, 99 S. Ct. 2077, 2084 (1979). 
1988's limitation to civil rights cases by appealing to the policy of liberal construction of civil rights laws must for these reasons be rejected. Absent any other explanation, the civil rights limitation must be classed as another of the unsolved mysteries of section 1988.

II. The Proper Scope of Segtion 1988

Because analysis reveals no attractive reading of section 1988, each unappealing alternative begins to grow in plausibility. It is possible, after all, that Congress passed an essentially meaningless statute. And the Republic would no doubt survive even if Congress did enact a federal statute that places many federal civil rights questions at the mercy of state law. These views, however, ought to be embraced only as a last resort, in the absence of any plausible alternative. In this part, I propose an approach that avoids the objections to either extreme view of section 1988. This new reading of section 1988 provides a simple test for determining when federal law is deficient, gives a plausible meaning to the inconsistency clause, and offers insight into why Congress included criminal cases within the ambit of section 1988 but excluded cases not involving civil rights.

Courts have misinterpreted section 1988 because they have been asking the wrong questions about it. Instead of seeking the circumstances under which section 1988 should influence issues in federal civil rights cases, courts should be asking whether Congress intended section 1988 ever to incorporate state rules in federally created actions. That Congress did not so intend follows from viewing section 1988 in its historical context. As enacted, the precursor to the present section 1988 played a rational but limited role in the structure of federal civil rights legislation. That role, an instruction to federal courts to apply substantive state rules when adjudicating cases arising under state law, remains section 1988's only appropriate sphere of operation.

\section{A. Section 1988 in Original Context}

Section 1988 derives from section 3 of the Civil Rights Act of $1866,{ }^{92}$ and its original role can be gleaned by study of the 1866 Act's first three sections. Although the Act is lengthy, its structure, and section 1988's place in that structure, cannot be understood without reference to these sections, which provide:

[Sec. 1] ... [A]ll persons born in the United States . . . are hereby declared to be citizens of the United States; and 
such citizens, of every race and color . . . shall have the same right . . . to make and enforce contracts, to sue, be parties, and give evidence, to inherit, purchase, lease, sell, hold, and convey real and personal property, and to full and equal benefit of all laws and proceedings for the security of person and property, as is enjoyed by white citizens, and shall be subject to like punishment, pains, and penalties, and to none other, any law, statute, ordinance, regulation, or custom, to the contrary notwithstanding.

Sec. 2. ... [A]ny person who, under color of any law, statute, ordinance, regulation, or custom, shall subject, or cause to be subjected, any inhabitant of any State or Territory to the deprivation of any right secured or protected by this act . . . shall be deemed guilty of a misdemeanor, and, on conviction, shall be punished by fine not exceeding one thousand dollars, or imprisonment not exceeding one year, or both, in the discretion of the court.

Sec. 3. . . . [T] he district courts of the United States . . . shall have, exclusively of the courts of the several States, cognizance of all crimes and offences committed against the provisions of this act, and also, concurrently with the circuit courts of the United States, of all causes, civil and criminal, affecting persons who are denied or cannot enforce in the courts or judicial tribunals of the State or locality where they may be any of the rights secured to them by the first section of this act; and if any suit or prosecution, civil or criminal, has been or shall be commenced in any State court, against any such person, for any cause whatsoever ... such defendant shall have the right to remove such cause for trial to the proper district or circuit court .... The jurisdiction in civil and criminal matters hereby conferred on the district and circuit courts of the United States shall be exercised and enforced in conformity with the laws of the United States, so far as such laws are suitable to carry the same into effect; but in all cases where such laws are not adapted to the object, or are deficient in the provisions necessary to furnish suitable remedies and punish offences against law, the common law, as modified and changed by the constitution and statutes of the State wherein the court having jurisdiction of the cause, civil or criminal, is held, so far as the same is not inconsistent with the Constitution and laws of the United States, shall be extended to and govern said courts in the trial and disposition of such cause, and, if of a 
criminal nature, in the infliction of punishment on the party found guilty. ${ }^{93}$

Reading the statute without the benefit of later gloss, ${ }^{94}$ one might gather that it functioned in the following manner: section 1 defines a set of rights that cannot be denied on account of race; section 2 imposes criminal sanctions against those who, under color of law, deny the rights guaranteed by section 1 ; and section 3 provides further information about federal court vindication of the rights set forth in section 1 . Not surprisingly, section 3 provides, in the initial clause ending with the words "this act," for exclusive federal jurisdiction of section 2 criminal cases. The next clause, ending with the first semicolon, seems to give the federal courts original jurisdiction over all cases, civil and criminal, in which section 1 rights are denied or cannot be enforced in state courts. In the remaining language of its first sentence, section 3 allows for federal jurisdiction in cases commenced in state courts by giving the state-court defendant the right to remove to federal court when his section 1 rights are not enforceable in the state court. Finally, in what is now section 1988, the second sentence of section 3 sets forth guidance as to what law should govern in the actions over which the federal courts have been given jurisdiction by the preceding language. The operation of this last sentence can best be appreciated through the use of examples.

Assume that it is 1866 and Mr. X, a black man in a southern state, is charged by the state with criminal trespass. At his trial in state court, Mr. X wishes to testify in his own defense, but he is barred from testifying because state law deprives blacks of the power to testify in court. ${ }^{95}$ How would the three quoted sections of the 1866 Act function in such a case?

93 Id. $\$ \S 1-3$.

94 For the Supreme Court's analysis of $\$ I$ of the 1866 Act, see Runyon v. McCrary, 427 U.S. 160, 168-72 (1976); Jones v. Alfred H. Mayer Co., 392 U.S. 409 (1968). But see note 137 infra.

95 Prior to the Civil War, "negroes, mulattoes, Indians, and persons of mixed blood" in Mississippi were "incapable of being witnesses in any case whatever, except for or against each other." Miss. REv. CoDE ch. lxi, \$ xvii, art. 192, at 510 (1857). In the Mississippi Black Code adopted in November 1865, the testimonial disqualification was modified to permit "freedmen, free negroes and mulattoes" to testify when blacks were parties to the suit or were victims of behavior at issue in the suit. Act to Confer Civil Rights on Freedmen, ch. iv, \$4, 1865 Miss. Laws 83. In the examples used in this Article, I have not attempted to construct situations in which blacks would have been disqualified from testifying under the actual laws of any particular state. For my purposes it is enough that Congress knew of testimonial disqualifications, see, e.g., Conc. Grobe, 39th Cong., Ist Sess. 479 (1866) (remarks of Sen. Saulsbury, an opponent of the 1866 Act); id. 1121 (remarks of Rep. Rogers, a member of the committee from which the bill was reported); $i d$. 
Clearly the law preventing $\mathrm{Mr}$. $\mathrm{X}$ from testifying is unlawful under section 1 of the 1866 Act. Those enforcing the disqualifying statute seem criminally liable under section 2.96 What happens to the state court action in which Mr. X is being prosecuted? Under section 3, the state's failure to give Mr. X a trial at which he can testify, a violation of section $\mathrm{I}$, invests $\mathrm{Mr}$. $\mathrm{X}$ with the right to remove the criminal proceedings against him to the local federal district or circuit court. But after removal, nothing in the 1866 Act precludes the prosecution of Mr. X for the crime. Presumably, Mr. X's trial will go forward in federal court.

In contemplating how that trial is to proceed, the language of section 1988 originating in the second sentence of section 3 begins to make sense. Here there is a deficiency in federal law not merely because a federal statute fails to outline every detail of a federally created cause of action. The deficiency arises instead because the substantive rule sought to be vindicated by the court proceedings against $\mathrm{Mr} . \mathrm{X}$ is not even a creature of federal law. In short, the action "arises under" state law. Even in the days of a general federal common law, it made no sense for Mr. X to be tried in federal court on anything other than the charge for which he was being tried in state court prior to removal. The instructions of section 1988's predecessor are clear-in the prosecution removed from state court pursuant to section 3 of the Act, state substantive rules defining the crime must govern. With one exception, any other result would be nonsensical.

The exception arises when the crime for which Mr. $\mathrm{X}$ is being prosecuted is itself violative of section 1. Suppose that the southern state also makes it a crime for a black man to enter into a contract with a white man and that Mr. $\mathrm{X}$ is being prosecuted for having done so. ${ }^{97} \mathrm{Mr}$. $\mathrm{X}$ is unable to enforce a section 1 right in state

1160 (letter describing Mississippi Black Code), and sought to remedy them by $\$ 1$ of the 1866 Act.

96 See also Cong. Grobe, 39th Cong., 1st Sess. 1758 (1866) (remarks of Sen. Trumbull); id. 1778 (remarks of Sen. Johnson); id. 1837 (remarks of Rep. Lawrence). This possibility of official liability was a source of irritation to some, particularly those who felt judges and legislators might be liable. See id. 500 (remarks of Sen. Cowan); id. 598 (remarks of Sen. Davis); id. 602 (remarks of Sen. Hendricks); id. 1680 (President Johnson's veto message); id. 1778 (remarks of Sen. Johnson).

97 Racially defined crimes in the Black Codes included miscegenation, Act to Confer Civil Rights on Freedmen, ch. iv, §3, 1865 Miss. Laws 82 (a form of discrimination to which the 1866 Act may not have been addressed, see Conc. GLOBE, 39th Cong., Ist Sess. 504-07 (1866) (exchange among Sens. Johnson, Trumbull, \& Fessenden)), and attempting to persuade a Negro worker to leave his employer before the expiration of the term of service, or employing, feeding, or clothing such a Negro, Act to Confer Civil Rights on Freedmen, ch. iv, $\$ 9,1865$ 
court-the right to make and enforce contracts. But now removal to federal court and continued prosecution pursuant to state criminal law will not afford Mr. X much relief. When his problem was merely that state law disqualified him from testifying, removal to federal court could eliminate the disqualification, and the prosecution could continue in a manner not violative of Mr. X's section 1 rights. But when the statute under which he is being prosecuted itself violates section 1 of the 1866 Act, it will not do merely to remove to federal court and allow the prosecution to go forward. A prosecution in any forum under a law that violates section 1 is prohibited. This is the purpose of the inconsistency clause of section 3, which ensures that state law (or, more accurately, the common law as modified by state law) will be used to cure deficiencies in federal law only if the state law is "not inconsistent with the Constitution and laws of the United States." Thus, although the prosecution of Mr. X for criminal trespass might go forward in federal court after removal, with state substantive criminal law defining the proscribed behavior, the inconsistency clause of section 3 prevents a state criminal law that violates section 1 from having force in the removed proceedings. In such cases, dismissal of the removed action seems the only appropriate course. ${ }^{98}$

Under the first three sections of the 1866 Act, incorporation of state substantive law is not limited to criminal cases. If $\mathrm{Mr}$. $\mathrm{X}$ is a defendant in a civil action in state court and state law denies him the right to testify because of his race, section 3 again authorizes removal and state substantive civil rules govern in the removed proceeding.

Under section 3 of the Civil Rights Act of 1866, it appears that section 1988's precursor was also intended to function in some cases originally brought in federal court. Assume that Mr. $\mathrm{X}$ is the victim of some tortious behavior and that he wishes to bring a civil action under state tort law. Assume further that Mr. X must testify on his own behalf if his tort case is to succeed, but that, as in the preceding hypothetical cases, state law bars Mr. X from testifying. There will not be much point to filing his tort claim in state court because Mr. X's inability to testify will assure the claim's failure. The language in the first sentence of section 3, providing federal

Miss. Laws 85. For the relation between the passage of the Black Codes and the 1866 Act, see C. Fatrman, 6 History of tHE SUPREME CourT of the UNTTED STATES: RECONSTRUCTION AND REUNTON 1864-88, at 1226-28 (1971).

98 The unavoidability of dismissing the removed action when the state law giving rise to it is inconsistent with federal law may provide insight into why $\S 1988$ provides no choice-of-law rule in this situation, see note 82 supra. If dismissal of the action is the only recourse, no need for further instruction exists. 
courts with original jurisdiction over all cases affecting persons who are either denied or cannot enforce their section 1 rights in state court, here comes to Mr. X's rescue. Because he is denied his section 1 right to testify by state law, Mr. X can bring his tort action originally in federal court without wasting his time in state court. ${ }^{99}$ In the federal court action, the precursor to section 1988 instructs the federal court to apply the state's law of torts.

By viewing section 1988 in the context of the 1866 Act one may give content to what is now section 1988 without having to read it as allowing state law to modify federally created rights. In all of the examples just discussed, section 3's reference to state law becomes relevant either when an action is removed from state to federal court or, as in the last example, when an original federal court action seeks to enforce state law. According to this view of section 3 , it permits substantive state law to operate in a federal forum only in cases arising under state law, a situation that occurs if state law denies to black persons the rights secured by section 1 of the 1866 Act.

In addition to conferring removal and original federal jurisdiction for state-created causes of action, the first sentence of section 3 of the 1866 Act conferred upon federal courts exclusive jurisdiction of prosecutions brought under section 2 of the Act. This third basis of jurisdiction raises a final possible class of cases in which section 3 might be read to require resort to state law in a federally created action. Section 2 criminal cases constitute actions arising under a federal law; that section is followed in the text of the statute by section 3, authorizing resort to state law. Even if one accepts that section 1988's precursor in the second sentence of section 3 did not contemplate use of state law in actions arising under other federal laws, the question remains whether it mandated resort to state law in the federal criminal actions created by the 1866 Act itself. For a number of reasons, it seems unlikely that Congress intended to do so.

First, section 3's grant of jurisdiction over section 2 criminal prosecutions to the federal district courts "exclusively of the courts of the several States" indicates that Congress perceived these cases as having a uniquely federal nature. If anything, one would expect these cases to be less dependent than other cases upon state law. Second, for the reasons canvassed in part $I,{ }^{100}$ it is unlikely that

${ }^{99}$ See Amsterdam, supra note 29 , at 813 n.88, suggesting that $\$ 3$ of the 1866 Act confers original jurisdiction "in the case of persons who are denied or cannot enforce their $\$ 1$ rights in the state courts."

100 See text accompanying notes 83-89 supra. 
section 3 was meant to have any application to federal criminal cases. Third, it is possible to give a plausible interpretation to the second sentence of section 3 without having it require resort to state law in criminal prosecutions under section 2. That sentence begins by stating that the federal jurisdiction conferred by the 1866 Act "shall be exercised and enforced in conformity with the laws of the United States, so far as such laws are suitable to carry the same into effect," 101 and goes on to provide for the use of state law when federal law is deficient. If the first part of the sentence, that requiring exercise of jurisdiction in conformity with federal law, is read to refer to section 2 as well as to other federal laws, and the rest of the sentence is read to refer only to state-created causes of action, then section 3 would never mandate applying state law to criminal prosecutions under federal law. If, as in the case of section 2 criminal cases, one finds an applicable federal law to interpret, one need not resort to state law. In such cases, section 2 is "the law of the United States" in conformity with which federal jurisdiction shall be exercised. State law is irrelevant because federal law is not deficient. Thus, nothing in this third basis for federal jurisdiction requires federal courts to use state law in actions arising under federal law.

Assuming for the moment that subsequent statutory developments ${ }^{102}$ have not altered the original understanding of section 1988's antecedents in section 3 of the Civil Rights Act of 1866, the reading that emerges-that section 1988 requires resort to state law only in cases arising under state law-avoids all of the seemingly insurmountable difficulties raised by other interpretations. First, the difficult problem of deciding when federal law is deficient disappears. One need no longer apply an artificial magnifying glass to section 1983 or to other federal civil rights statutes to determine whether they address an issue. Federal law is deficient within the meaning of section 1988 only when a substantive state rule, civil or criminal, is the source of the action..$^{103}$ This limited interpretation eliminates the awkwardness of having a federal law mandate resort

101 Civil Rights Act of 1866, ch. 31, $\$ 3,14$ Stat. 27 (current version codified at 42 U.S.C. $\$ 1988$ (1976)).

102 For this later development, see text accompanying notes 117-22 infra.

103 In one sense, the proposed test for deficiency in federal law replaces existing difficulties with new ones. For the question whether an action "arises under" federal law is not always easily answered. See generally Mishkin, The Federal "Question" in the District Courts, 53 CouvM. L. Rev. 157 (1953). Nevertheless, in the vast majority of cases, and in all cases raising federal constitutional and statutory civil rights claims, there should be little difficulty in ascertaining the source of law for the action. 
to state rules in cases involving primarily questions of federal policy. Under this interpretation, section 1988 never mandates adherence to state rules in actions arising under section 1983, or any other federal law. Indeed, as originally enacted, section 1988 could not have been meant to influence section 1983 actions because the initial version of section 1983 did not become law until five years later. ${ }^{104}$

Second, the new approach to section 1988 supplies a reading of the inconsistency clause that does no violence to ordinary meaning; state laws are inconsistent with federal law only if they violate it. And because the inconsistency clause is not activated unless the action arises under state law, there is no longer any need to stretch the definition of "inconsistent" to include state laws that significantly restrict the federal cause of action, or to find state laws inconsistent on one set of facts but not on another.

Third, the new approach solves the puzzles of section 1988's inclusion of criminal cases. Section 1988 neither authorizes creation of a mysterious new class of crimes based on state law nor mandates use of state procedural rules in federal criminal prosecutions. It simply instructs federal courts to apply state criminal law when state criminal prosecutions are removed to federal court.

Finally, the mystery of section 1988's limitation to civil rights cases is resolved. In addition to providing exclusive federal jurisdiction over federal criminal prosecutions brought against persons who violated the civil rights guaranteed by section 1 , the Civil Rights Act of 1866 also took the unusual step of conferring federal jurisdiction over cases arising under state law in which section 1 rights were implicated. The provisions in section 3 concerning the law to be applied in the exercise of those jurisdictional grants were naturally limited to these civil rights actions, there being no need or reason to formulate a rule for any other kind of case.

\section{B. Legislative History of Section 1988}

I do not pretend that the text of the 1866 Act and the previous discussion prove conclusively that section 3's command to apply state law was meant to operate only in cases arising under state law.

104 Although $\S 1983$ 's origins are traceable in part to language in $\$ 2$ of the Civil Rights Act of 1866, see, e.g., Chapman v. Houston Welfare Rights Org., 99 S. Ct. 1905, 1921 (1979) (Powell, J., concurring), there was no general federal cause of action for violation of constitutional rights until passage of the Ku Klux Klan Act of 1871, ch. 22, 17 Stat. 13, $\$ 1$ of which is the direct ancestor of the present $\$ 1983$. Section 2 of the 1866 Act merely criminalized acts taken under color of law that violated $\S 1$ of the 1866 Act. See text accompanying note 93 supra. 
It is possible, consistently with the English language, to read the second sentence of section 3 to apply to federal claims as well. But the case for a new interpretation of section 1988 rests on more than the investigation of section 1988's original context and on the weakness of alternative readings; the argument draws modest but important support from the legislative histories of the 1866 Act and of later relevant provisions. Nowhere in those histories do members of Congress suggest that section 1988's progenitor required application of state law in any case other than one arising under state law.

Understandably, section 3 did not receive the lion's share of attention during Congress's consideration of the 1866 Act. ${ }^{105}$ The substantive rights set forth in section 1 were hotly debated, ${ }^{106}$ and the criminal sanctions in section 2 drew much fire from opponents. ${ }^{107}$ Section 3's significance was dwarfed by the importance of the preceding sections. When it was mentioned, however, the discussion supported the view that section 3 imported state law into federal court only in cases arising under state law.

Senator Trumbull, who introduced the bill that became the 1866 Act, made the following preliminary remarks about section 3:

[The third section of the bill] provides further that no person whose equal civil rights are denied him in the State courts shall be tried by those courts for any offense, but that he shall have a right to remove his cause into the courts of the United States, and be there tried if it be for an offense against the laws of the United States, according to those laws, and if it be for an offense which is not provided for by the laws of the United States, then according to the common law as modified by the statutes and constitution of the State where the offense is committed, so far as they are not inconsistent with the Constitution and laws of the United States. ${ }^{108}$

Senator Trumbull's description alludes to the use of state law only in cases removed from state court in which the offense was not provided for by federal law. There is no hint that section 3 might mandate application of state law in federal causes of action.

105 Amsterdam, supra note 29, at 811-14 (discussing the removal feature of $\S 3$ of the 1866 Act).

106 See, e.g., Cong. Globe, 39th Cong., Ist Sess. 1271 (1866) (remarks of Rep. Kerr). See generally C. FAIRMAN, supra note 97, at 1172-1204.

107 See Cong. Grobe, 39th Cong., Ist Sess. 500 (1866) (remarks of Sen. Cowan); id. 598 (remarks of Sen. Davis); id. 602 (remarks of Sen. Hendricks); id. 1679-81 (President Johnson's veto message); id. 1778 (remarks of Sen. Johnson). 108 Id. 475. 
Opponents of the act seemed to agree that section 3's references to state law operated in cases of removal. Senator Saulsbury, in challenging the constitutionality of the 1866 Act, pointed to cases similar to those of Mr. X:

Suppose that an action of ejectment is instituted in any State where free negroes are denied the right to testify, and suppose that action of ejectment is against a free negro. He wishes to prove that he has not been guilty of the trespass in ejectment, and he proposes to prove it by a negro, and the court say [sic], "No; under the law of this State that negro is not a competent witness." In such a case as that, this bill authorizes the circuit or district court of the United States to take cognizance of that action of ejectment, and the State courts are excluded from its consideration. ${ }^{109}$

In hearing the ejectment action, there could be little choice but to apply state ejectment rules. Senator Saulsbury also objected to the fact that the Act allowed for removal of criminal cases.

Take another case. A free negro commits murder in the State of Kentucky. He is indicted under the laws of Kentucky in the State courts. ... He calls up a negro. ... The judge in Kentucky ... would say under their law that this negro could not be a witness. What does this bill provide? It provides that that case of murder shall be taken from the jurisdiction and control of the State courts, and that the district and circuit courts of the United States shall have exclusive jurisdiction of it. ${ }^{110}$

Whatever objections Senator Saulsbury had to removal of the criminal case, he assumed that the murder trial would go forward in federal court under the state's substantive law of murder. President Johnson's message vetoing the 1866 Act also indicated that state law would determine the outcome of cases removed under section 3 in which the offense was not within the purview of federal law. ${ }^{111}$

109 Id. 479.

110 Id. See also id. 598-99 (remarks of Sen. Davis).

111 It is clear that in States which deny to persons whose rights are secured by the first section of the bill any one of those rights, all criminal and civil cases affecting them, will, by the provisions of the third section, come under the exclusive cognizance of the Federal tribunals. It follows that if, in any State which denies to a colored person any one of all those rights, that person should commit a crime against the laws of the State, murder, arson, rape, or any other crime, all protection and punishment 
It is tempting to overread this admittedly sparse legislative history. The conclusive, positive statement always yearned for by future generations is missing. But omissions may be as instructive as positive statements. No member of Congress mentioned cases in which section 3 would mandate incorporation of state law other than in cases arising under state law and removed to federal court.

An irony emerges in contrasting the reason that today's Court gives for its interpretation of section 1988 with the reasons given in 1866 for opposing section 3. In Robertson $v$. Wegmann, ${ }^{112}$ the only cogent reason the Court gives for applying section 1988 to incorporate Louisiana's survivorship law is that if section 1988 does not mandate use of state law in that case, it might never do so. Yet opponents of section 1988's predecessor objected that the provision was part of a section, one providing for removal, that would operate in too many cases. ${ }^{113}$ How can both of these positions have been entertained? The answer, of course, is that in 1866 several states had provisions that, on their face, violated section 1 of the 1866 Act. Saulsbury and others referred to them in the debates. ${ }^{114}$ In such states removal was expected to be a frequent occurrence, and section 3 's invocation of state law would be frequently called upon in the removed cases. Today, there are no state laws comparable to the Black Codes which section 1 was designed to overcome. In the absence of such blatantly unlawful provisions, civil rights removal has become exceedingly rare, ${ }^{115}$ and the instruction to resort to state law in removed cases has suffered a corresponding reduction in importance. Section 1988, as the successor to the second sentence of section 3, deserves a similar fate. This is not to say, however, that the provision was passed without a purpose, but only that the

through the courts of the State are taken away, and he can only be tried and punished in the Federal courts. How is the criminal to be tried? If the offense is provided for and punished by Federal law, that law, and not the State law, is to govern.

It is only when the offense does not happen to be within the purview of the Federal law that the Federal courts are to try and punish him under any other law. Then resort is to be had to "the common law, as modified and changed" by State legislation, "so far as the same is not inconsistent with the Constitution and laws of the United States." So that over this vast domain of criminal jurisprudence, provided by each State for the protection of its own citizens, and for the punishment of all persons who violate its criminal laws, Federal law, wherever it can be made to apply, displaces State law.

Id. 1680 (President Johnson's veto message).

112436 U.S. 584 (1978).

113 See, e.g., Cong. GlobE, 39th Cong., 1st Sess. 47 (1866) (remarks of Sen.

Saulsbury); id. 1680 (President Johnson's veto message).

114 See notes 95 \& 97 supra \& text accompanying notes 109-10 supra.

115 See note 143 infra \& accompanying text. 
problems it was intended to remedy are no longer real. Contrary to the Supreme Court's assertion in Robertson, ${ }^{116}$ one need never apply section 1988 to fill gaps in section 1983 or other federal civil rights statutes in order to avoid rendering section 1988 meaningless. If states were to pass statutes similar to the Black Codes, both the removal provisions and section 1988 would again be of central importance.

Because the words now constituting section 1988 were originally part of the 1866 Act the major focus in divining their meaning from secondary sources should be on the history of that Act. The postCivil War burst of federal civil rights legislation, however, extended well beyond 1866, and some of the later developments bear upon section 1988. The 1866 Act was followed by proposal of the fourteenth amendment in $1866,{ }^{117}$ its ratification in $1868,{ }^{118}$ and ratification of the fifteenth amendment in 1870.119 With these new sources of power Congress embarked upon a civil rights program that included the Enforcement Act of $1870^{120}$ and the Ku Klux Klan Act of 1871.121 Both Acts incorporate by reference provisions of the 1866 Act, ${ }^{122}$ including section 3, and it is therefore necessary to consider their effect on that portion of section 3 from which section 1988 derives.

In the 1870 Act, Congress dealt primarily with voting rights. ${ }^{123}$ Passed only two months after ratification of the fifteenth amendment, the Act was intended to guarantee in practice the right to vote that the new amendment secured in theory. Given that Congress's primary concern was with voting rights, ${ }^{124}$ and that the provisions of the 1870 Act relating to the 1866 Act were not the focus of substantial discussion, ${ }^{125}$ it is unlikely that in enacting those provisions Congress meant to work substantial changes in section 1988's pre-

116436 U.S. at 593.

117 H.R.J. Res. 127, 39th Cong., 1st Sess., CoNg. Guobe 2286, 3042 (1866).

11815 Stat. 708 (1868) (ratification certified by Secretary of State William H. Seward).

11916 Stat. 1131 (1870) (ratification certified by Secretary of State Hamilton Fish).

120 Ch. 114, 16 Stat. 140.

121 Ch. 22, 17 Stat. 13.

122 Enforcement Act of 1870, ch. 114, $\$ 18,16$ Stat. 140; Ku Klux Klan Act of 1871 , ch. $22, \S 1,17$ Stat. 13.

123 See ch. 114, $\$ 11-5,9,14,15$, \& 19-23, 16 Stat. 140; 1 B. Schwartz, Statutory History of the United States: Crvin Rrghts 443 (1970).

124 See, e.g., Cong. GloBE, 4lst Cong., 2d Sess. 3558-71, 3607-16 (1870). As originally introduced the 1870 Act dealt only with voting rights. Id. 3503-04.

125 Cong. Globe, 4lst Cong., 2d Sess. (1870), contains an index to the debates on the Enforcement Act. 
cursor. Nor does anything in the 1870 Act suggest a contrary result.

Section 18 of the 1870 Act reenacted the 1866 law and provided that two new sections, analogous to sections 1 and 2 of the 1866 Act, were to be enforced according to the earlier Act's provisions. ${ }^{126}$ In reenacting the 1866 statute, the 1870 Act created no situations in which reference to state law in federal causes of action would be any more necessary than it had been under the 1866 Act. All the removal cases that could have arisen under the 1866 Act could arise as well under the 1870 Act. Thus, the passage of the 1870 Act in no way requires adjustments to the interpretation of section 3 of the 1866 Act advanced here.

The structure of the 1870 Act contains subtler evidence bearing on the likely intended scope of section 3 of the 1866 Act. Section 1 of the 1870 Act states a general principle outlawing discrimination in voting. ${ }^{127}$ Sections 2 through 6 of the Act define a series of federal crimes for interfering with federally protected rights. ${ }^{128}$ Sec-

126 Sections 16-18 of the 1870 Act provided:

Sec. 16. ... [A]ll persons within the jurisdiction of the United States shall have the same right in every State and Territory in the United States to make and enforce contracts, to sue, be parties, give evidence, and to the full and equal benefit of all laws and proceedings for the security of person and property as is enjoyed by white citizens, and shall be subject to like punishment, pains, penalties, taxes, licenses, and exactions of every kind, and none other, any law, statute, ordinance, regulation, or custom to the contrary notwithstanding. No tax or charge shall be imposed or enforced by any State upon any person immigrating thereto from a foreign country which is not equally imposed and enforced upon every person immigrating to such State from any other foreign country; and any law of any State in conflict with this provision is hereby declared null and void.

Sec. 17. . . . [A]ny person who, under color of any law, statute, ordinance, regulation, or custom, shall subject, or cause to be subjected, any inhabitant of any State or Territory to the deprivation of any right secured or protected by the last preceding section of this act, or to different punishment, pains, or penalties on account of such person being an alien, or by reason of his color or race, than is prescribed for the punishment of citizens, shall be deemed guilty of a misdemeanor, and, on conviction, shall be punished by fine not exceeding one thousand dollars, or imprisonment not exceeding one year, or both, in the discretion of the court.

Sec. 18. ... [T] [The act to protect all persons in the United States in their civil rights, and furnish the means of their vindication, passed April nine, eighteen hundred and sixty-six, is hereby re-enacted; and sections sixteen and seventeen hereof shall be enforced according to the provisions of said act.

Ch. 114, $\S \S 16-18,16$ Stat. 140 (1870). For an explanation of linguistic differences among $\S 1$ of the 1866 Act, $\S 16$ of the 1870 Act, and current 42 U.S.C. $\$ 1981$ (1976), see Runyon v. McCrary, 427 U.S. 160, 195 n.6 (1976) (White, J., dissenting); Amsterdam, supra note 29 , at 818 n.105.

127 Enforcement Act of 1870, ch. 114, § 1, 16 Stat. 140.

$128 I d$. $\$ \$ 2-6$. 
tion 8, which outlines the role of the federal courts in vindicating the rights established by the new Act, a function identical with that of section 3 of the 1866 Act, provides:

[T] he district courts of the United States, within their respective districts, shall have, exclusively of the courts of the several States, cognizance of all crimes and offences committed against the provisions of this act, and also, concurrently with the circuit courts of the United States, of all causes, civil and criminal, arising under this act, except as herein otherwise provided, and the jurisdiction hereby conferred shall be exercised in conformity with the laws and practice governing United States courts; and all crimes and offences committed against the provisions of this act may be prosecuted by the indictment of a grand jury, or, in cases of crimes and offences not infamous, the prosecution may be either by indictment or information filed by the district attorney in a court having jurisdiction. ${ }^{129}$

It is instructive to contrast this provision with the related provision set forth in section 3 of the 1866 Act. The first few lines of the two sections are identical. Yet in the remaining language there are differences significant for this inquiry. First, Congress omitted from section 8 of the 1870 Act any reference to removal such as that contained in section 3 of the 1866 Act. This omission is understandable because the provisions preceding section 8 in the 1870 Act create federal crimes or rights of action. Given the exclusive federal jurisdiction provided for in the first clause of section 8 , there are no state law claims to be removed to federal court. Second, unlike the 1866 Act, the 1870 Act gives federal courts neither original nor removal jurisdiction over any state law claims. More

129 Id. $\$ 8$. Interestingly, $\S 8$ of the 1870 Act and $\S 18$ 's incorporation of the 1866 Act (including $\$ 3$ ) gave the 1870 Act two provisions instructing the federal courts how to exercise their jurisdiction. Only one of those provisions, $\S 3$ of the 1866 Act as incorporated by $\$ 18$ of the 1870 Act, contained a choice-of-law rule and a removal provision. This means that a court following the instructions in $\$ 3$ of the 1866 Act might allow removal of state prosecutions to federal court whereas a court following the instructions in $\$ 8$ of the 1870 Act might find authority for such removal wanting.

The two jurisdictional provisions can be reconciled by treating $\$ \$ 16-18$ of the 1870 Act as a separate enactment that is regulated by the jurisdictional instructions of $\S 3$ of the 1866 Act. This view finds support in $\$ 18$ 's text, which instructs courts to enforce $\$ \S 16$ and 17 of the 1870 Act according to the provisions of the 1866 Act. See note 126 supra. Statutory authority for this reading also comes from $\S 8$ of the 1870 Act because $\$ 8$ instructs courts to exercise their jurisdiction in accordance with that section "except as herein otherwise provided."

The absence of a choice-of-law rule in cases of exclusive federal jurisdiction recurs in the Civil Rights Act of $1875, \mathrm{ch} .114, \$ 3,18$ Stat. 335. 
importantly, the absence from section 8 of those jurisdictional grants is accompanied by the absence of the language in section 3 from which section 1988 derives. This omission supports the view that such language was meant to operate when actions arising under state law were removed to or originated in federal court. Where there was no possibility that a state law claim would be adjudicated in federal court, there simply was no need for language equivalent to section 1988.

The $\mathrm{Ku}$ Klux Klan Act of $1871^{130}$ was the last significant civil rights provision to incorporate portions of the 1866 Act. ${ }^{131}$ After creating a federal civil action for violations of federal rights in language substantially the same as that found now in section 1983, section 1 of the 1871 Act provides in part: "[S]uch proceeding [is] to be prosecuted in the several district or circuit courts of the United States, with and subject to the same rights of appeal, review upon error, and other remedies provided in like cases in such courts, under the provisions of [the Civil Rights Act of 1866] . . ."132 Given the 1871 Act's reference to the remedial structure of the 1866 Act, one might ask whether Congress meant to apply the choice-oflaw provision contained in section 3 of the 1866 Act to the federal cause of action created by the 1871 Act. If so, then section 3's directive that state law govern would apply to actions arising under federal law, and the thesis advanced here would be undermined.

It is doubtful that Congress's reference to the 1866 Act was so intended. Initially, as suggested by the interpretation offered above of the application of section 3 to section 2 criminal cases, ${ }^{133}$ Congress expressly limited resort to state law to cases arising under state law. The same reference in section 3 to the exercise of jurisdiction "in conformity with the laws of the United States" that rendered section 3's invocation of state law inapplicable to section 2 criminal

130 Ch. 22, 17 Stat. 13.

131 The later revisions of the federal civil rights statutes that tinker with the 1866 Act's language were not intended to work substantive changes. See note 136 infra.

$132 \mathrm{Ku}$ Klux Klan Act of 1871, ch. $22, \S 1,17$ Stat. 13. The part of $\S 1$ that preceded the portion quoted in the text read:

[A]ny person who, under color of any law, statute, ordinance, regulation, custom, or usage of any State, shall subject, or cause to be subjected, any person within the jurisdiction of the United States to the deprivation of any rights, privileges, or immunities secured by the Constitution of the United States, shall, any such law, statute, ordinance, regulation, custom, or usage of the State to the contrary notwithstanding, be liable to the party injured in any action at law, suit in equity, or other proper proceeding for redress ....

133 See text accompanying notes 100-01 supra. 
prosecutions could be viewed as rendering state law inapplicable to cases arising under all other federal laws. If Congress entertained different notions with respect to the cause of action set out in section 1 of the 1871 Act, one would expect the change to have been expressly noted in statutory language or reflected in the congressional debates. Yet nothing in the text or the legislative history of the 1871 Act indicates that the reference to the 1866 Act was meant to require federal courts to fill the gaps in section 1983's progenitor with the law of the state in which they sat. ${ }^{134}$

In addition, section 2 of the 1866 Act was a model for section 1 of the 1871 Act. The latter was in part intended to add civil remedies to the criminal penalties already provided by the former. ${ }^{135}$ Viewed in this light, the language of the 1871 Act, referring to "like cases" under the 1866 Act, acquires a special significance. Of the three classes of cases over which federal jurisdiction was granted in the 1866 Act-section 2 criminal cases, cases arising under state law brought originally in federal court, and cases removed from state to federal court-the first of these three was most "like" the cases to be brought under section 1 of the 1871 Act. Therefore, the reference in section 1 to "like cases" under the 1866 Act could be interpreted as singling out those cases arising under section 2 of the 1866 Act. If so, then section 1 of the 1871 Act need not be viewed as ever requiring that state law govern actions arising under it. In them, just as in criminal actions arising under section 2 of the 1866 Act, federal law would always be "adapted to the object" and never deficient.

The last significant step in section 1988's transformation from its foundations in the 1866 Act to its current isolation in Title 42 consists of what were supposed to have been nonsubstantive revisions of the United States Code. In 1866, Congress authorized an organizational revision of all United States statutes. ${ }^{136}$ The task,

134 Cong. Globe, 42d Cong., 1st Sess. (1871), contains an index to the debates on the 1871 Act. Section 1 was the least controversial provision of the Act. See, e.g., Chapman v. Houston Welfare Rights Org., 99 S. Ct. 1905, 1912 \& n.25 (1979); Developments in the Law-Section 1983 and Federalism, 90 HARv. L. REv. 1133, 1155 (1977). (1979).

135 Chapman v. Houston Welfare Rights Org., 99 S. Ct. 1905, 1912 n.25

136 The Act of June 27, 1866, ch. 140, $\$ 1,14$ Stat. 74, authorized the President to appoint a commission "to revise, simplify, arrange, and consolidate all statutes of the United States, general and permanent in nature." No substantive changes were supposed to be made in the course of the revision, see Chapman v. Houston Welfare Rights Org., 99 S. Ct. 1905, 1919 (1979) (Powell, J., concurring); Note, Federal Jurisdiction: The Civil Rights Removal Statute Revisited, 1967 Duke L.J. 136, 140 \& n.14, a guideline followed with questionable success. See note 137 infra. 
completed in 1874, separated substantive civil rights provisions, such as section 1 of the 1866 Act, from their jurisdictional and procedural counterparts. ${ }^{137}$ In the course of those revisions, section 3 of the 1866 Act was separated from the rest of what was originally the 1866 Act, and splintered into a removal provision, section 641 of the Revised Statutes, ${ }^{138}$ and a choice-of-law provision identical to section 1988, section 722 of the Revised Statutes. ${ }^{130}$ This separation of section 3 into separate removal and choice-of-law provisions may have been the most significant development in section 1988's history. For viewed in its original context, as part of the 1866 Act, there is little doubt that section 1988 was meant to function primarily in removal cases arising under state law. Yet when viewed in isolation, section 1988 becomes sufficiently ambiguous to deceive courts into believing that it dictates a choice-of-law rule in civil rights cases arising under federal law. Cut adrift from the only provision with respect to which it made any sense, section 1988 seems to take on a life of its own, and the attempt by courts to define the limits of that artificial existence predictably has led to great confusion.

137 The substantive rights protected by $\$ 1$ of the 1866 Act and by $\S 16$ of the 1870 Act became $\$ \S 1977-1978$ of the Revised Statutes. 18 Stat. 347 (1875). Jurisdiction over such cases, as well as over the cases provided for by the 1871 Act, was provided by $\$ \S 563$ and 629 of the Revised Statutes. 18 Stat. 94 (1875) (district courts); id. 110 (circuit courts). Both jurisdictional provisions, however, required action "under color of" law. Given the Supreme Court's later interpretation of $\$ 1$ of the 1866 Act to reach private racial discrimination, see Runyon v. McCrary, 427 U.S. 160, 170 (1976); Jones v. Alfred H. Mayer Co., 392 U.S. 409, 426-36 (1968), it is doubtful that, as drafted, the jurisdictional counterparts in the Revised Statutes successfully provided for jurisdiction for this important class of cases. In Jones itself, the Court purported to find district court jurisdiction in 28 U.S.C. $\$ 1343(4)$ (1976), see 392 U.S. at 412 n.l, a broadly worded measure that Congress labeled a technical amendment to the 1957 Voting Rights Act. See Chapman v. Houston Welfare Rights Org., 99 S. Ct. 1905, 1912 \& n.24, 1916-17 \& $\mathbf{n . 3 8}$ (1979).

The Revision's separation of civil rights provisions into substantive and nonsubstantive components has caused repeated difficulty in attempts to give meaning to Reconstruction era legislation. In addition to the difficulties with $\$ 1988$, the division of $\$ 1$ of the $\mathrm{Ku}$ Klux Klan Act of 1871 into jurisdictional and substantive provisions has complicated jurisdictional questions in civil rights cases. See Chapman v. Houston Welfare Rights Org., 99 S. Ct. 1905 (1979); Hague v. CrO, 307 U.S. 496 (1939). The intended scope of $\$ 1$ of the 1866 Act may also have been obscured by its separation into the contemporary $\$ \$ 1981$ and 1982 and their isolation from the jurisdictional and removal provisions that originally accompanied $\S 1$. See C. FAIRMAN, supra note 97, at 1248-57; Casper, Jones v. Mayer: Clio, Bemused and Confused Muse, 1968 Sup. Cт. REv. 89. And the isolation of the removal provisions of $\$ 3$ of the 1866 Act from the rest of that statute has hampered the Supreme Court's attempts to articulate a role for the surviving civil rights removal section, 28 U.S.C. \$ 1443 (1976). See Amsterdam, supra note 29, at 842-82.

13818 Stat. 115 (1875). This provision is the predecessor of 28 U.S.C. $\$ 1443$ (1976). See Georgia v. Rachel, 384 U.S. 780, 786 (1966).

13918 Stat. 137 (1875). 


\section{Consequences of a Limited View of Section 1988}

The realization that section 1988 mandates application of state law only in state-created causes of action gives rise to two series of questions, each leading in turn to new doctrinal paths. The first involves the doctrine of Erie Railroad $v$. Tompkins. ${ }^{140}$ When substantive state law governs the claim being tried in federal court, may judges, in light of the Erie doctrine, tolerate a different result in the federal forum than would be reached by a state court trying the same action? Of course, if the substantive state law itself violates federal law, then the inconsistency clause of section 1988 mandates a different result in the federal forum. But apart from such cases, the question whether to follow federal or state rules persists. To illustrate, assume $\mathrm{Mr} . \mathrm{X}$ is a defendant in a civil case in a state court in a state that prohibits blacks from testifying. Mr. $\mathrm{X}$, in 1866 and today, may remove the state court civil case to federal court. ${ }^{141}$ Except for the federal rule substituting for the state's testimonial disqualification, are federal rules to be applied in the removed proceeding when they might lead to results different from those that would be reached by the state court using state rules? Although it is tempting to plunge ahead with what, in the Erie tradition, might turn out to be an endless analysis of this question, demanding appropriate sensitivity to the particular federal rule in question and the true meaning of the Rules of Decision Act, ${ }^{142} \mathrm{I}$

140304 U.S. 64 (1938).

14128 U.S.C. $\S 1443$ (1) (1976). See, e.g., Georgia v. Rachel, 384 U.S. 780, 803-04 (1966); Strauder v. West Virginia, 100 U.S. 303, 310-12 (1879).

14228 U.S.C. $\$ 1652$ (1976), which provides: "The laws of the several states, except where the Constitution or treaties of the United States or Acts of Congress otherwise require or provide, shall be regarded as rules of decision in civil actions in the courts of the United States, in cases where they apply." The provision was first enacted as $\$ 34$ of the Judiciary Act of $1789, \mathrm{ch} .20, \S 34$, I Stat. 92.

One further puzzle surrounding $\$ 1988$ is why, even properly interpreted, it was necessary in light of the Rules of Decision Act. Would not that Act mandate use of state law in cases arising under state law that happen to be tried in federal court? A number of responses are possible. First, some believe that the Rules of Decision Act has no application in nondiversity cases. See Campbell v. Haverhill, 155 U.S. 610, 614 (1895); Comment, Rules of Decision in Nondiversity Suits, 69 YALE L.J. 1428, 1431 (1960). Under such a view, $\$ 1988$ would provide guidance in a large class of cases-nondiversity suits-not governed by the Rules of Decision Act. Second, $\$ 1988$ can be viewed as an attempt by Congress to clarify the relationship between federal and state law in civil rights cases by making clear that, within their sphere of operation, Reconstruction era civil rights statutes displaced applicable state law. Third, even if the Rules of Decision Act were believed to be applicable to nondiversity cases, $\$ 1988$ might have been thought necessary because Swift v. Tyson, 41 U.S. (16 Pet.) I (1842), had limited the Rules of Decision Act to refer only to state statutes and "local" common law rules. See Comment, supra, at 1433. Section 1988 can then be viewed as expanding what might otherwise have been the use of state law in removal cases to include state common law rules. Finally, it is possible that Congress simply did not have the then 77-year-old Rules of Decision Act in mind when it enacted what is now $\$ 1988$. 
trust I will be forgiven for not doing so. Today, the cases in which section 1988 will give rise to a federal court trial of a state cause of action are virtually nonexistent. Civil rights removal is all but a dead letter, ${ }^{143}$ and the state statutes, the Black Codes, that might have enabled a Reconstruction era litigant to bring state law claims as an original matter in federal court no longer exist.

The second series of questions generated by new insight into section 1988 is of more immediate relevance. With section 1988 out of the picture there seems momentarily to be a void in the federal civil rights program. If section 1988 provides no guidance, how should courts deal with issues they have been handling or mishandling by reference to section 1988?

The answer is not surprising. Federal courts should fill out the federal civil rights program by the same techniques used to fill out other federal programs. These techniques are not reducible to facile formulae but they have been explored with sophistication by others, a process I see no reason to repeat here. ${ }^{144}$ The result may be that state law will govern some matters, ${ }^{145}$ but this in no way discredits the limited interpretation of section 1988. For once section 1988 is restricted to its proper scope, the decision whether to apply state law is no longer coerced by congressional command. The new approach leaves federal courts room to maneuver, while undertaking a careful analysis of the propriety of borrowing the state rule in the particular case. And in deciding whether to adopt or reject the state rule, the courts need no longer embarrass themselves by mangling or ignoring section 1988.

143 Compare Georgia v. Rachel, 384 U.S. 780 (1966), with City of Greenwood v. Peacock, 384 U.S. 808 (1966). See Johnson v. Mississippi, 421 U.S. 213 (1975); Note, supra note 136, at 188 \& n.257, 190; Comment, Civil Rights Removal After Rachel and Peacock: A Limited Remedy, 121 U. PA. L. Rev. 351, 376-77 (1972). 144 See generally Friendly, supra note 56; Hart, The Relations Between State and Federal Law, 54 Conum. L. Rev. 489 (1954); Mishkin, The Variousness of "Federal Law": Competence and Discretion in the Choice of National and State Rules for Decision, 105 U. PA. L. REv. 797 (1957); Note, supra note 48; Note, The Competence of Federal Courts to Formulate Rules of Decision, 77 Harv. L. Rev. 1084 (1964); Comment, supra note 37; Comment, supra note 142.

$145 \mathrm{See}$, e.g., the recommended uses of state law in $\$ 1983$ cases in Comment, supra note 37 , at 500-06. 